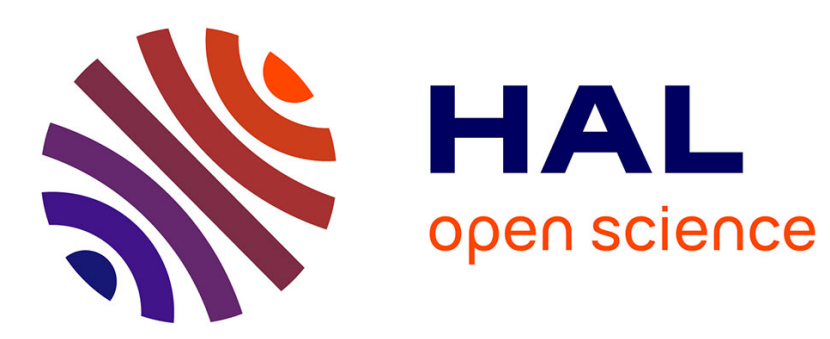

\title{
Relating orogen width to shortening, erosion, and exhumation during Alpine collision
}

\author{
Claudio L. Rosenberg, A Berger, Nicolas Bellahsen, R Bousquet
}

\section{To cite this version:}

Claudio L. Rosenberg, A Berger, Nicolas Bellahsen, R Bousquet. Relating orogen width to shortening, erosion, and exhumation during Alpine collision. Tectonics, 2015, 34 (6), pp.1306-1328. 10.1002/2014TC003736 . hal-01176225

\section{HAL Id: hal-01176225 \\ https://hal.sorbonne-universite.fr/hal-01176225}

Submitted on 15 Jul 2015

HAL is a multi-disciplinary open access archive for the deposit and dissemination of scientific research documents, whether they are published or not. The documents may come from teaching and research institutions in France or abroad, or from public or private research centers.
L'archive ouverte pluridisciplinaire $\mathbf{H A L}$, est destinée au dépôt et à la diffusion de documents scientifiques de niveau recherche, publiés ou non, émanant des établissements d'enseignement et de recherche français ou étrangers, des laboratoires publics ou privés. 


\section{Tectonics}

\section{RESEARCH ARTICLE}

10.1002/2014TC003736

Key Points:

- Alps width correlates with amount of syncollisional shortening and exhumation

- Size of the accreted lower plate wedge decreases with increasing shortening

- Along strike changes of shortening, not climate, control orogen width

Correspondence to:

C. L. Rosenberg,

claudio.rosenberg@upmc.fr

\section{Citation:}

Rosenberg, C. L., A. Berger, N. Bellahsen, and R. Bousquet (2015), Relating orogen width to shortening, erosion, and exhumation during Alpine collision, Tectonics, 34, doi:10.1002/2014TC003736.

Received 10 SEP 2014

Accepted 21 APR 2015

Accepted article online 24 APR 2015

\section{Relating orogen width to shortening, erosion, and exhumation during Alpine collision}

\author{
C. L. Rosenberg ${ }^{1,2}$, A. Berger ${ }^{3}$, N. Bellahsen ${ }^{1,2}$, and R. Bousquet ${ }^{4}$ \\ ${ }^{1}$ Sorbonne Universités, UPMC Université Paris 06, Paris, France, ${ }^{2}$ CNRS, Paris, France, ${ }^{3}$ Institut für Geologie, University of \\ Bern, Bern, Switzerland, ${ }^{4}$ Institute of Geosciences, University of Kiel, Kiel, Germany
}

Abstract We investigate along-strike width changes of the thickened, accreted lower plate (TALP) in the Central and in the Eastern Alps. We set the width of the TALP in relation to the inferred amount of collisional shortening and exhumation along six orogen-scale cross sections. Taking the present-day, along-strike gradients in the amount of collisional shortening to represent the temporal evolution of the collisional wedge, it may be concluded that the cross-sectional area of the TALP diminishes during ongoing shortening, indicating that the erosional flux outpaced the accretionary flux. Higher amounts of collisional shortening systematically coincide with smaller widths of the TALP and dramatic increases of the reconstructed eroded rock column. Higher amounts of shortening also coincide with larger amplitudes of orogen-scale, upright folds, with higher exhumation and with higher exhumation rates. Hence, erosion did play a major role in reducing by $>30 \mathrm{~km}$ the vertical crustal thickness in order to accommodate and allow shortening by folding. Long-term climate differences cannot explain alternating changes of width by a factor of almost 2 along straight segments of the orogen on length scales less than $200 \mathrm{~km}$, as observed from the western Central Alps to the easternmost Eastern Alps. Sedimentary or paleontological evidences supporting such paleo-climatic differences are lacking, suggesting that erosional processes did not directly control the width of the orogen.

\section{Introduction}

The width of orogens may change through time depending on the rate and amount of shortening, on the efficiency of erosion, on the strength and thickness of the plates, or on the occurrence of preexisting and newly formed weaknesses within the plates. Out of these parameters, the effect of erosion rates is the one that has been modeled more systematically [e.g., Beaumont et al., 1999; Willett, 1999; Konstantinovskaia and Malavieille, 2005; Hoth et al., 2006; Whipple, 2009], showing that erosion rates are inversely correlated to orogen width. This relationship can be explained using the theory of critical tapers, which predicts that thinning of wedges due to erosion leads to shortening, hence thickening of the wedge, in order to maintain a constant taper angle [e.g., Dahlen, 1990]. Alternatively, it can be shown analytically [Molnar and Lyon-Caen, 1988] that the work and the potential energy needed to thicken the crust during collision increase proportionally to the square of the crustal thickness involved. This leads to the nucleation of new thrusts in the foreland and to the widening of the mountain chain unless erosion maintains the thickness of the crust more or less constant.

Many attempts to test the results of these models on natural orogens focused on the Alpine chain (Figure 1) [e.g., Schlunegger, 1999; Willett et al., 2006; Willett, 2010; Cederboom et al., 2011], because the wealth of geological data in this orogen allows one to correlate paleo-erosional data [Kuhlemann et al., 2002] with reconstructions of orogen-scale shortening [e.g., Schmid et al., 1996] and width through time [e.g., Schlunegger, 1999; Rosenberg and Berger, 2009]. Several studies [e.g., Schlunegger and Simpson, 2002; Willett et al., 2006] claimed that climate-driven changes of erosional efficiency controlled the changes of width of the Alps throughout the Tertiary. In particular, it was suggested that erosion rates dramatically increased after the Messinian [Kuhlemann et al., 2002], thus reducing the orogen width [Willett et al., 2006]. Other studies concluded on the base of structural and geochronological compilations that the inferred post-Messinian increase of erosion rates coincided with an increased growth of the Alps into their forelands and not with a reduction of width [Rosenberg and Berger, 2009]. Irrespectively of their interpretations, all the studies above discussed the relationship between paleo-orogen width and paleo-erosion rates, based on retrodeformation of the orogen along the NFP20 cross section in the Central Alps and on the reconstructed sediment budgets
@2015. American Geophysical Union. All Rights Reserved. 


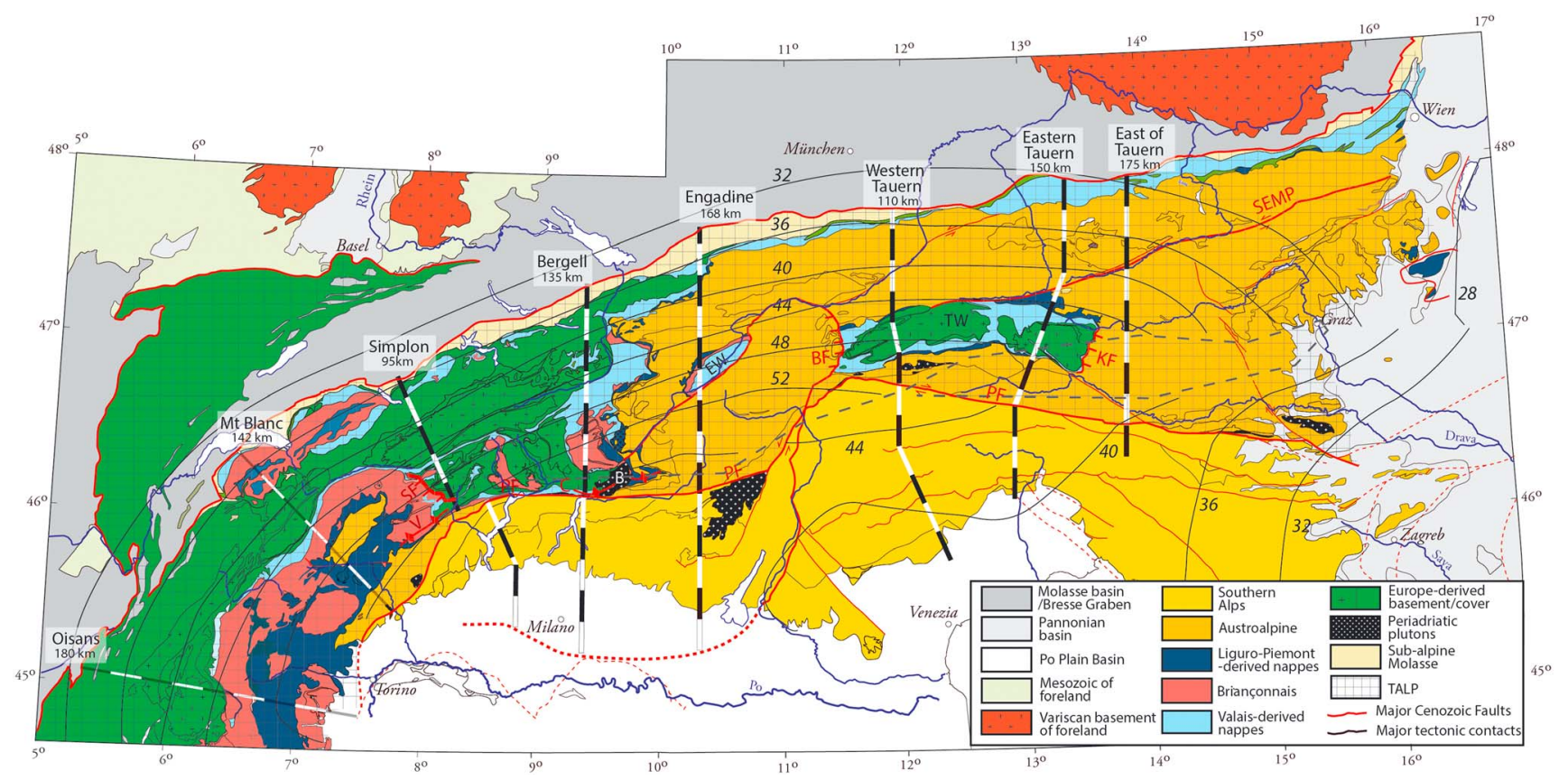

Figure 1. Simplified tectonic map of the Alps, modified from Bousquet et al. [2012]. The black grid indicates the surface extension of the TALP (thickened accreted lower plate). Traces of the six sections of Figure 3 are indicated by thick lines. Thinner section traces in the Western Alps are not shown in Figure 3. The continuous black lines indicate Moho contours after Spada et al. [2013]. The stippled gray lines define area below which the position of the Moho cannot be located [Spada et al., 2013]. Italic numbers indicate Moho depth in kilometer. EW: Engadine Window, TW: Tauern Window, BF: Brenner Fault, KF: Katschberg Fault, PF: Periadriatic Fault, SF: Simplon Fault, SEMP : Salzach-Ennstal-Mariazell-Puchberg Fault, C: Cressim antiform, and V: Vanzone antiform. The black numbers north of each section indicate length of TALP in kilometer along that section. Note that these length values are measured along a straight line between the endpoints of the section, not along the broken line used to construct the sections.

of the peri-Alpine foreland basins [Kuhlemann et al., 2002]. However, these data, which point to dramatic increases of sedimentation rates after the Messinian, are flawed by many uncertainties, related to the preservation of the sediments, to the origin of the sediments, which is not confined to the Alpine orogen, and to the absolute age of the sediments. Additional doubts on the validity of the inferred paleo-erosion rates originate from independent, geochemical proxys that do not indicate any increase of erosion rates after the Messinian [Willenbring and von Blanckenburg, 2010]. Reconstructions of the orogen width through time also go together with important uncertainties. Retrodeformation of the internal domains is poorly constrained due to the lack of sedimentary markers and to the unknown depth of basal detachments of thrusts. Finally, the interpretation of temporal correlations between changes of width and erosion rates, even if these two parameters were known, is not straightforward, because it depends on the "response time" of the orogen to the onset of climatic forcing [Tomkin and Roe, 2007]. Assessing the response time for a natural orogen requires numerous, generally poorly constrained, assumptions on its paleorheology.

This paper contributes to the understanding of the factors controlling the width of the Alps during collision by correlating present-day along-strike variations of width of the Central and Eastern Alps with inferred lateral changes in the amounts of exhumation and shortening during collision. Based on this correlation, we discuss the causes controlling orogen width and long-term erosion rates along the strike of the Alpine chain. In contrast to previous studies [e.g., Willett et al., 2006; Rosenberg and Berger, 2009], the present approach does not base its interpretations on paleo-erosional rates and paleowidths of the Alps at different stages of its Miocene evolution, thus avoiding to include large bias on the determination of these parameters and to address the problem of response times, that is difficult to determine in a natural orogen [Tomkin and Roe, 2007].

\section{Geologic Background}

The Alps are a bivergent type of orogen [Argand, 1916], which resulted from subduction and complete closing of two oceanic domains [Froitzheim et al., 1996], from the Late Cretaceous to the upper Eocene, followed by a 


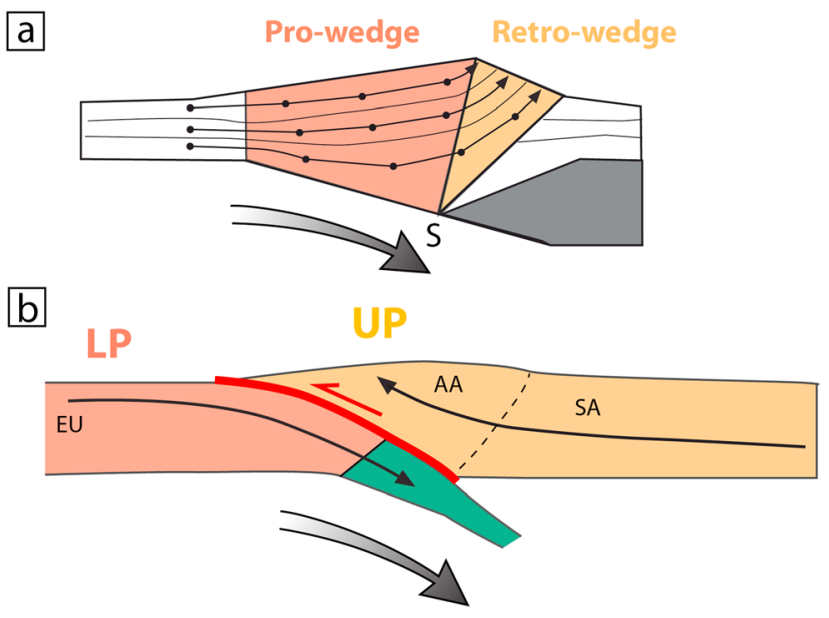

C

Figure 2. (a) Schematic cartoon modified after Willett et al. [1993], showing the position of prowedge and retrowedge and lower plate particle paths in relation to a velocity discontinuity at the plate interface. (b) Schematic cross section showing the upper Adriatic plate, the subducting oceanic plate and the European plate during the subduction phase of Alpine orogeny. The black arrows indicate trajectories of material points. (c) Schematic cross section showing the upper and lower plates of the Alpine orogen during the collisional stage. Vertical ruling shows the TALP which consists of both Austroalpine- and European-derived units. Comparing Figures $2 \mathrm{a}$ and $2 \mathrm{c}$ indicates that the TALP forms the entire prowedge, in addition to large parts of the retrowedge. Thick red lines indicate the upper plate boundary. LP: lower plate, UP: upper plate, TALP: thickened accreted lower plate, AA: Austroalpine, SA: Southern Alps, and EU: European plate.

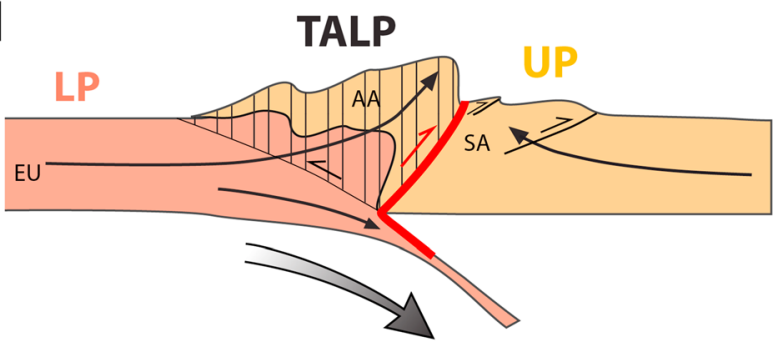

continent-continent collision from the Oligocene to the present. Based on the age of high-pressure rocks [Berger and Bousquet, 2008] and of sedimentation in the Molasse Basins [e.g., Burkhard and Sommaruga, 1998], the transition from subduction of oceanic and/or transitional crust to continent-continent collision must have started in the late Eocene. In the following, we will use the term collision to describe the coeval subduction of continental mantle and accretion of continental crust.

Lithospheric scale cross sections based on the integrated interpretation of surface geology and reflection seismics [Pfiffner, 1993; Schmid et al., 1996; Lammerer and Weger, 1998; Schmid and Kissling, 2000; TRANSALP Working Group, 2002; Rosenberg and Kissling, 2013] (Figure 2) show that collision in the Alps involved subduction of the European mantle and part of the European lower crust below the Adriatic plate (Figure 2) as already suggested in the early cross sections of Argand [1916] and Laubscher [1988]. In contrast, the middle and upper parts of the European crust were detached from their lower crust, hence accreted and shortened, forming the northward vergent and the back thrusted belts of the orogenic wedge (Figure 2). We term this part of the orogen, which includes the entire prowedge, but also part of the retrowedge, the thickened accreted lower plate (TALP) [Rosenberg and Kissling, 2013] (Figure 2). In map view, the TALP can be defined as that part of the orogen that is confined between a backstop (northern margin of the Southern Alps; Figure 2) and the deformation front of the lower plate (northernmost thrust in the Molasse Basin). The TALP differs from the prowedge in the sense of Willett et al. [1993] because it also includes part of the retrowedge (Figure 2).

The upper plate of the Alpine collisional orogen corresponds to the Southern Alps (Figure 1), which are commonly inferred to represent indenters during collision, because they are less deformed than the accreted lower plate material [e.g., Ratschbacher et al., 1991], although this view is questionable in some parts of the orogen [Rosenberg and Kissling, 2013]. The Austroalpine units (Figures 1) formed part of the upper plate during subduction of the Alpine Tethysian oceans (Figure 2b), but they became welded on top of the lower plate and back thrusted with it on top of the upper plate during collision (Figure 2c). As a consequence, we consider the Austroalpine units as part of the upper plate during oceanic subduction but as part of the accreted lower plate during collision. From a paleogeographic point of view, both the Austroalpine units and the Southern Alps (Figure 1) form the southernmost plate involved in Alpine orogeny, generally referred to as Adria [Trümpy, 2002].

The TALP consists of a pile of nappes, derived from different paleogeographic domains. On the first order, insequence thrusting led to the progressive stacking of nappes whose present-day structural level is increasingly deeper for those units, whose paleogeographic position was located further north or northwest [e.g., Trümpy, 1980]. Hence, from bottom to top within the collisional wedge, the nappes are 
derived from the European continental plate, from the Valais oceanic plate [Stampfli, 1993; Steinmann and Stille, 1999], from the Briançonnais continental plate [e.g., Stampfli, 1993], from the Liguro-Piemont oceanic plate [Elter, 1971], and finally from the Adriatic plate. Out of these paleogeographic domains, the Briançonnais is the only one that is not continuous along strike in the Alps. It completely disappears east of the Engadine Window (Figure 1), and it was suggested that its disappearance corresponds to the original, pre-Alpine plate configuration, in which the Briançonnais domain wedges out eastward [Stampfli, 1993; Froitzheim et al., 1996].

In map view (Figure 1), the TALP gradually increases its width from west to east in the Central Alps, ranging from a minimum of $95 \mathrm{~km}$ in the Simplon area to a maximum of $170 \mathrm{~km}$ in the Engadine area. East of the Giudicarie fault system (Figure 1), there is an abrupt transition toward a much narrower TALP, which consists of only $112 \mathrm{~km}$ in the Brenner area and progressively increases eastward, attaining $178 \mathrm{~km}$ east of the Tauern Window (Figure 1).

A simple and qualitative relationship between width of the TALP and structural level exposed at the surface can be assessed from the tectonic map of Figure 1. Where the TALP is large in map view (e.g., Engadine section), the uppermost units of the Alpine nappe stack, i.e., the Austroalpine units, are exposed almost everywhere at the surface. These units, defined as orogenic lid by Laubscher [1983], remained in the brittle field throughout the collisional history of the Alpine orogen, as shown by the Cretaceous ages of cooling of thermochronometers such as fission track on zircons, with closing temperature close to that of the brittle-ductile transition [Handy and Oberhänsli, 2004]. In the central part of the Central Alps (Bergell section), the Austroalpine lid is almost completely eroded, and lower parts of the nappe stack are exposed at the surface (Figure 1), i.e., the Briançonnais units and parts of the distal European margin. Further west, along the Simplon section, where the TALP is narrowest, most of the units exposed belong to the deepest portions of the nappe stack, namely, to the European basement.

A similar trend is observed in the Eastern Alps. Where the TALP is shorter (western Tauern Window; Figure 1), the deepest level of the nappe stack, i.e., the European basement nappes (Figure 1), is exposed on large part of the section, and where the orogen is larger, only the uppermost units of the nappe stack, i.e., the Austroalpine (Figure 1) are exposed at the surface.

\section{Cross Sections, Exhumation Level, and Collisional Shortening}

In the following, we discuss the relationship between TALP width and shortening as estimated on a series of orogen-scale cross sections in the Central and Eastern Alps. Because the largest amount of collisional shortening is localized in the internal part of the orogen, from where sedimentary markers have been eroded, our shortening estimates only rely on area and line-length balancing of basement units. In spite of these difficulties, because the present study is mainly focused on the relative differences of shortening along the strike of the Alps, we do base our results on the shortening estimates of basement units for the Central Alps [Rosenberg and Kissling, 2013] and on a new set of values similarly obtained for the Eastern Alps. These shortening estimates neglect the occurrence of orogen-parallel extension that was mainly accommodated as strike-slip motion along the Periadriatic Fault, the Salzach-Ennstal-Mariazell-Puchberg (SEMP) Fault (Figure 1), and as normal displacement along the Simplon and the Brenner Faults (Figure 1). This extensional deformation points to material flow in a direction perpendicular to the plane in which shortening was estimated. Therefore, our inferred amount of shortening represents a minimum estimate only.

\subsection{Eastern Alps}

\subsubsection{East-of-Tauern Section (Figure 3a)}

This section is modified from Schmid et al. [2004, their Figure 3e] for the part north of the Periadriatic Line. The southern part of the section is redrawn from Nussbaum [2000]. The geometry of the TALP shows two major differences compared to the section of Schmid et al. [2004]. First, we straightened the Periadriatic Fault, making it steeper in its deeper part, hence consistent with its orientation further west and along the surface. Second, the dramatic thickness changes within the Austroalpine antiformal structures are reduced in our section by adding European basement within their hinge areas. The northernmost antiform in Schmid et al. [2004] terminates against the SEMP Fault, creating a distributed, differential uplift of 
approximately $20 \mathrm{~km}$ of the Austroalpine Mesozoic cover [Schmid et al., 2004]. This uplift is observed across the SEMP Fault further west, where its cause can be attributed to a thickening of the European basement (Figures $3 \mathrm{~b}$ and $3 \mathrm{c}$ ). Therefore, we consider it likely that the antiforms of Figure $3 a$ are cored by European basement.

If the two antiformal structures are filled by European crust, folding must be post-Eocene, as inferred for the onset of shortening in the European basement [e.g., Schmid et al., 2013]. Indeed, apatite fission track ages along this section are younger in the two areas corresponding to these antiforms [Wölfler et al., 2011, their Figure 4], where ages vary between 15 and $19 \mathrm{Ma}$. Zircon fission track ages are very rare in these areas; however, two samples from the area east of the Tauern Window and west of the East-of-Tauern section (Figure 1) yield ages of 35 and $13 \mathrm{Ma}$ [Bertrand, 2013], suggesting that Cenozoic exhumation may have been more significant than previously thought.

The surface exposure of the TALP throughout the entire cross section consists of Austroalpine basement and its cover (North Calcareous Alps) in addition to a thin sliver of nonmetamorphic Penninic units (Rhenodanubian Flysch; Figure 1) at the northern end of the section. No deep-seated units of the Cenozoic nappe stack are exhumed to the surface, and the nappe stack is mostly subhorizontal or gently south dipping within the TALP.

\subsubsection{Eastern Tauern Window (Figure $3 b$ )}

This section is compiled from Nussbaum [2000] for the Southern Alps, from Brix and Schultz [1993] for the area north of the SEMP Fault, and newly constructed for the Tauern Window, although partly based on Exner [1964] and Schmid et al. [2013]. The Moho depth is taken from Spada et al. [2013]. The base of the uppermost European basement nappe is constrained from surface geology, whereas the lower nappes are only sketched by assuming an average thickness of approximately $7 \mathrm{~km}$, as suggested by the cross section further west (Figure 3c), where several nappe contacts are exposed at the surface. This section coincides with the large-scale antiformal stack of the Tauern Dome, exposing the European basement nappes in the core and the oceanic Valais and Liguro-Piemont units in the limbs. As in the previous section, this structure is confined between the Periadriatic Fault in the south and the SEMP Fault in the north, two strike-slip fault systems which were also affected by significant amounts of vertical displacement in order to accommodate the differential uplift the European basement nappes, as shown in the sections (Figures $3 a$ and $3 b$ ). North of the latter antiformal stack, no evidence for shortening affecting the European basement is known. Displacements affecting the most external thrusts in the Subalpine Molasse are modest [Ortner et al., 2015] and may be in kinematic continuity with the deepest nappe below the Tauern Window uplift (Figure 3b).

\subsubsection{Western Tauern Window (TRANSALP; Figure 3c)}

This section coincides with the TRANSALP seismic section [e.g., TRANSALP Working Group, 2002]. The shape and height of the first-order antiformal hinge, forming the Tauern Dome, is projected from the fold hinges exposed further west, as in Schmid et al. [2013]. The structure of the Southern Alps is taken from Castellarin and Cantelli [2000]; the one of the TALP north of the Tauern Window is modified from Auer and Eisbacher [2003], Behrmann and Tanner [2006], and Ortner et al. [2006]. Structures above the surface are similar to those of previous interpretations [Lammerer and Weger, 1998; Lammerer et al., 2008, 2011], but they differ significantly at depth. Following Bleibinhaus and Groshup [2008], we constructed the Periadriatic Fault as a vertical structure down to $\sim 15 \mathrm{~km}$ depth; however, we did not rotate it into a gently south dipping orientation as in the latter work. Considering that this structure forms the boundary of the Dolomites indenter, whose relative northward displacement induced severe shortening and dextral strike slip down to deep levels of the nappe pile, we prefer to maintain a steep orientation of the Periadriatic Line even below $15 \mathrm{~km}$ depth.

The structure of the TALP in cross section (Figure 3c) is similar to the one of the eastern Tauern section (Figure $3 \mathrm{~b}$ ) because it consists of one major antiformal structure, exposing the European basement in its core. However, the amplitude of the fold is larger than that of the eastern Tauern section, and it also affects much of the Austroalpine units south of the Tauern Window. Whereas the European nappe stack was only eroded by a couple of kilometers above the core of the eastern Tauern Dome, approximately $10 \mathrm{~km}$ of the same nappe stack was eroded in the western Tauern section (compare Figures $3 \mathrm{~b}$ and $3 \mathrm{c}$ ). However, the N-S extent of this nappe stack is approximately half of that of the eastern Tauern section (compare Figures $3 \mathrm{~b}$ and $3 \mathrm{c}$ ). 

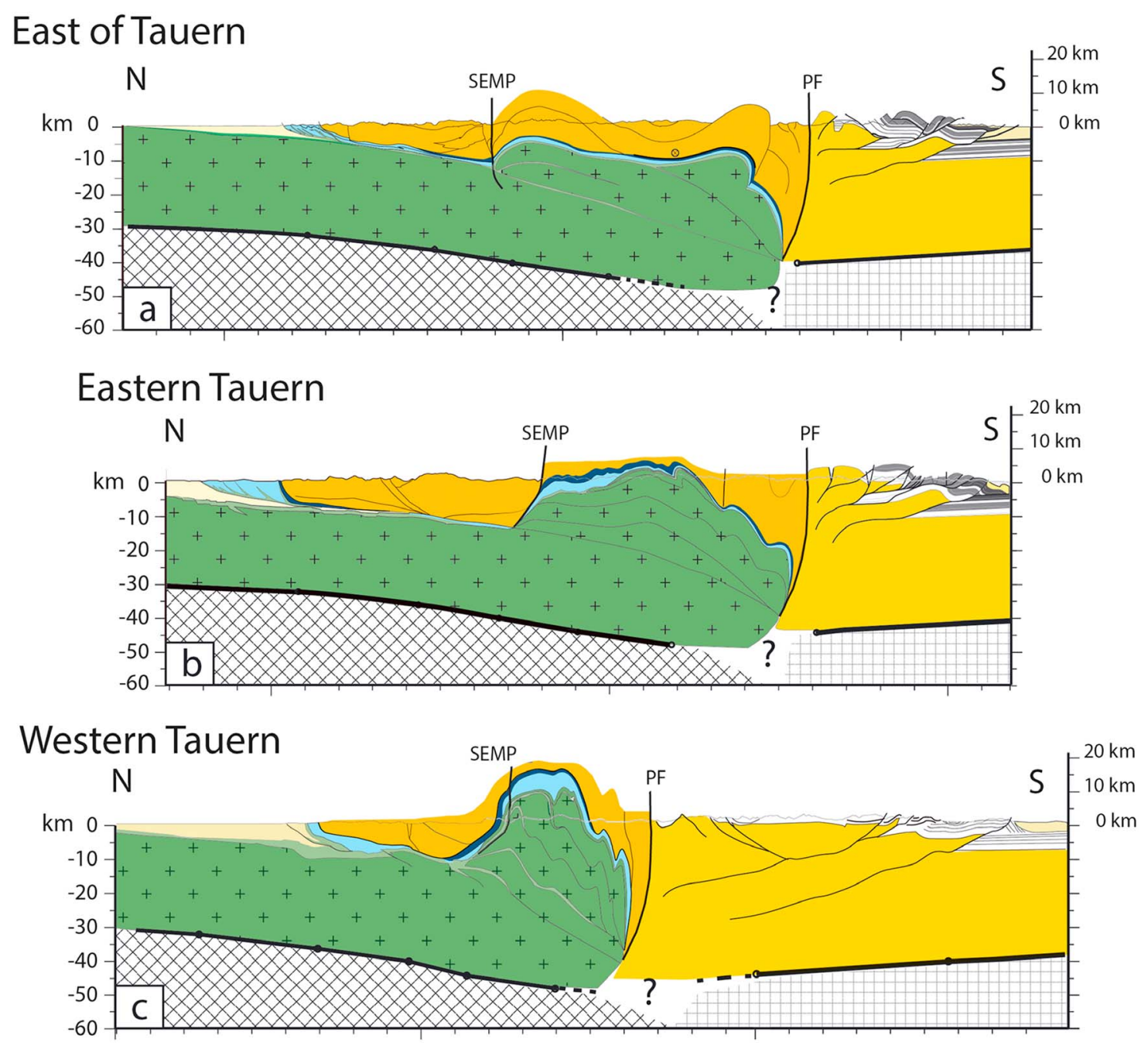

\begin{tabular}{|c|c|c|c|c|c|}
\hline & Molasse & $\begin{array}{l}\text { Valais-derived } \\
\text { nappes }\end{array}$ & $\begin{array}{l}\text { Liguro-Piemont } \\
\text {-derived nappes }\end{array}$ & Austroalpine & Adriatic mantle \\
\hline \begin{tabular}{|l}
+ \\
+
\end{tabular} & $\begin{array}{l}\text { European } \\
\text { basement }\end{array}$ & $\begin{array}{l}\text { Briançonnais } \\
\text { basement }\end{array}$ & $\begin{array}{l}\text { South- Alpine } \\
\text { basement }\end{array}$ & $\begin{array}{l}\text { Periadriatic } \\
\text { plutons }\end{array}$ & $\mathrm{MOHO}$ \\
\hline & $\begin{array}{l}\text { European } \\
\text { cover }\end{array}$ & $\begin{array}{l}\text { Briançonnais } \\
\text { cover }\end{array}$ & $\approx \Omega_{\text {Sover }}^{\text {South-Alpine }}$ & EX European mantle & $\begin{array}{l}\text { Major tectonic } \\
\text { contacts }\end{array}$ \\
\hline
\end{tabular}

Figure 3. Orogen-scale cross sections through the Eastern Alps. (a) East-of-Tauern section, (b) eastern Tauern section, (c) western Tauern section (TRANSALP), (d) Engadine section, (e) Bergell section, and (f) Simplon section. The thick black lines indicate the Adriatic and the European Moho, whose depth is taken from the contour lines (black circles) of Spada et al. [2013]. Thick and stippled black lines: extrapolation of the Moho in areas where the Moho cannot be located [Spada et al., 2013]. The question marks underline the incertitude about the deep structure in the contact area of the two Mohos [Spada et al., 2013]. Thin black lines: major tectonic contacts. PF: Periadriatic Fault and SEMP: Salzach-Ennstal-Puchberg-Mariazell Fault.

\subsubsection{Collisional Shortening and Metamorphism in the Eastern Alps}

Assuming that the Periadriatic Fault was a straight and E-W striking structure throughout the Central and Eastern Alps in the Oligocene [e.g., Laubscher, 1990; Pomella et al., 2011], Linzer et al. [2002] calculated that post-Oligocene shortening in the TALP varied between $54 \mathrm{~km}$ in the western Tauern section to $37 \mathrm{~km}$ in the easternmost Tauern Window. Collisional shortening along the entire TRANSALP section was estimated to $150 \mathrm{~km}$ [Rosenberg and Berger, 2009] based on line-length balancing of the Tauern Dome structure and previous literature on the Southern Alps. The Tauern antiform was inferred to accommodate $49 \mathrm{~km}$ of shortening [Rosenberg and Berger, 2009], whereas recent studies suggest $32 \mathrm{~km}$ [Schmid et al., 2013]. These differences result from the fact that line-length balancing was calculated from the reconstructed surface down to different depths. The line length of the reference surface in cross section was considered down to $-10 \mathrm{~km}$ only in Schmid et al. [2013]. In spite of the more speculative character of these calculations 

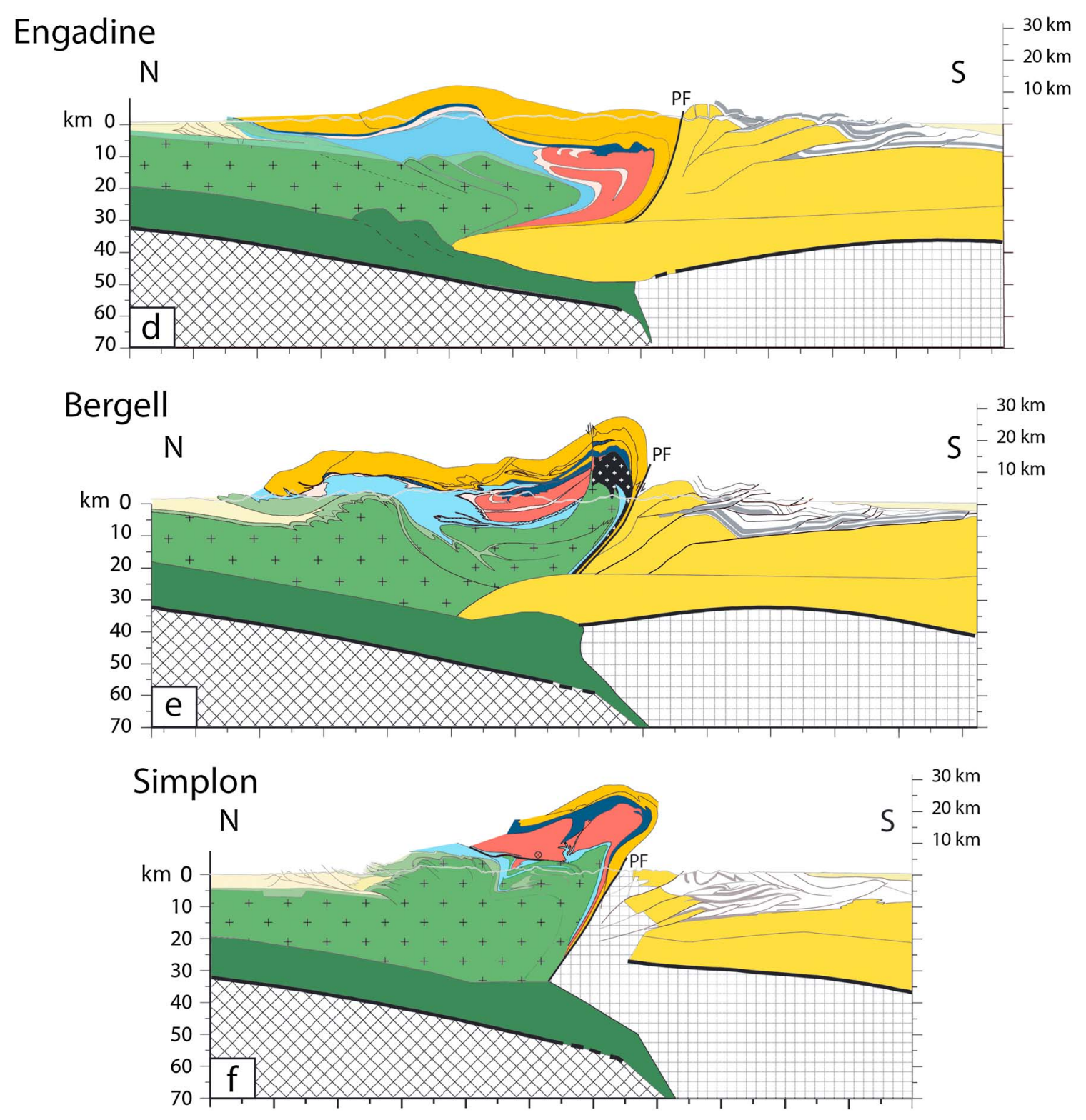

Figure 3. (continued)

at depth, where the geometrical control on the structures is not as sound as in the areas closer to the surface, such line-length calculations on the entire antiformal stack of European basement of Figure $3 \mathrm{c}$ yields $60 \mathrm{~km}$ of shortening. The same calculations for the eastern Tauern sections yield 39 and $27 \mathrm{~km}$ of shortening, respectively.

Comparing the three sections above (Figure 4a) shows a progressive westward increase of exhumation level associated to the amplification of antiformal folding of the European basement nappes and all units lying above them. This increase in the exhumation level is also expressed by an increase in the temperature of Alpine, high-temperature (HT) metamorphism (Figure 5), which reaches temperatures $>650^{\circ} \mathrm{C}$ in the western Tauern Window, of $>600^{\circ} \mathrm{C}$ in the eastern and central Tauern Window, and is entirely lacking east of the Tauern Window. Extensional unroofing along the Brenner and Katschberg normal faults certainly contributed to the exhumation of high-temperature metamorphic rocks in these areas [Selverstone, 1988; Genser and Neubauer, 1989], but temperatures do correlate to the different amplitude of upright folds observed in Figures 3a-3c. Unfortunately, the scarcity of pressure data within the Tauern Window does not allow one to recognize any possible pressure trends, which would give more direct information about the amount of exhumation attained in different areas. 

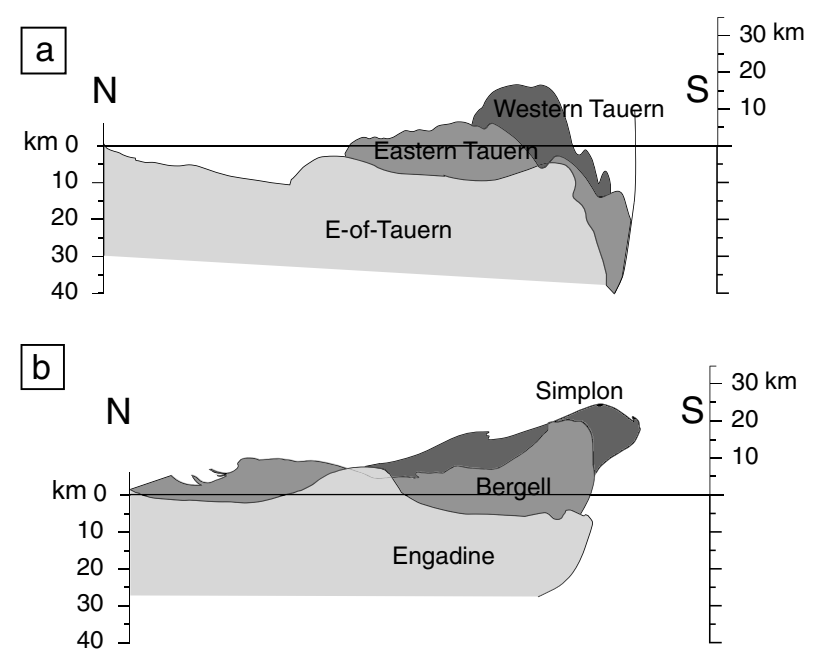

Figure 4. Comparison of exhumation level for the different cross sections. Each gray shading indicates the geometry of all units of one cross section lying below the reconstructed base of the Austroalpine. Hence, the different altitudes attained by the gray shadings are a measure for the different amounts of exhumation attained in each section. The horizontal line is a reference marker at $0 \mathrm{~m}$ above sea level altitude. (a) Eastern Alps. (b) Central Alps. fold of large amplitude (Cressim antiform; Figure 1), hence datable at 31-28 Ma. Based on these observations, we restrict the use of postnappe folding structures to the time interval between $31 \mathrm{Ma}$ and the present. In the following, we will refer to this time interval when discussing shortening during collision.

\subsubsection{Engadine Section (Figure 3d)}

The TALP consists of a stack of subhorizontal to gently south dipping nappe that abruptly steepens and becomes overturned north of the Periadriatic Fault (Figure 3d). Further north, the only thick-skinned type of deformation of the nappe stack is a low-amplitude and large-wavelength antiform that forms the Engadine Window (Figure 3d), inferred to accommodate 10-12 km of shortening [Hitz, 1995]. Recent investigations suggest that the Subalpine Molasse thrust belt, in the area of the Engadine section, was affected by an Oligocene-Miocene shortening of $\sim 30 \mathrm{~km}$ [Ortner et al., 2015]. These thrusts must be rooted in the European basement further south and indicate that collisional shortening previously inferred along this section of the TALP [Hitz, 1995; Rosenberg and Kissling, 2013] was underestimated.

Within the Engadine Window, the Valaisan and Briançonnais units were exhumed in the Oligocene [Evans, 2011], whereas the remaining surface of the TALP only consists of Austroalpine units that cooled below $300^{\circ} \mathrm{C}$ in the Cretaceous [Luth and Willingshofer, 2008]. Hence, neither shortening nor exhumation was very significant in the TALP of the Engadine section. Indeed, the inferred complete overturning of the deepseated nappe roots in the southern part of the TALP (Figure 3d) must be associated to a large deformation, but the latter is related to the $\sim 60 \mathrm{~km}$ detachment interpreted to separate the lower from the middle and upper Adriatic crust (Figure $3 \mathrm{~d}$ ). This structure is compensated by midcrustal and upper crustal thrusts of the upper plate (Figure 3d) that accommodated $87 \mathrm{~km}$ of shortening during the Miocene based on section balancing [Schönborn, 1992]. Hence, most part of postnappe shortening of the Engadine section is localized in the upper plate not in the TALP.

In terms of the level of exhumation, this section (Figure 3d) is similar to the East-of-Tauern section. Both show a modest thickness of the antiformal nappe stack (Figure 4) and a subhorizontal to gently south dipping orientation of all first-order structures of the TALP.

\subsubsection{Bergell Section (Figure 3e)}

The nappe stack of the TALP (Figure 3e) is shortened by two orogen-scale postnappe folds: the largeamplitude Cressim fold (Figure 1) in front of the South Alpine indenter and the larger wavelength antiform forming the Aar Massif (Figure 1) further north. Between these antiforms, there is a large area of approximately $50 \mathrm{~km}$ length, in which the European nappes and the above-lying Valais and Briançonnais 

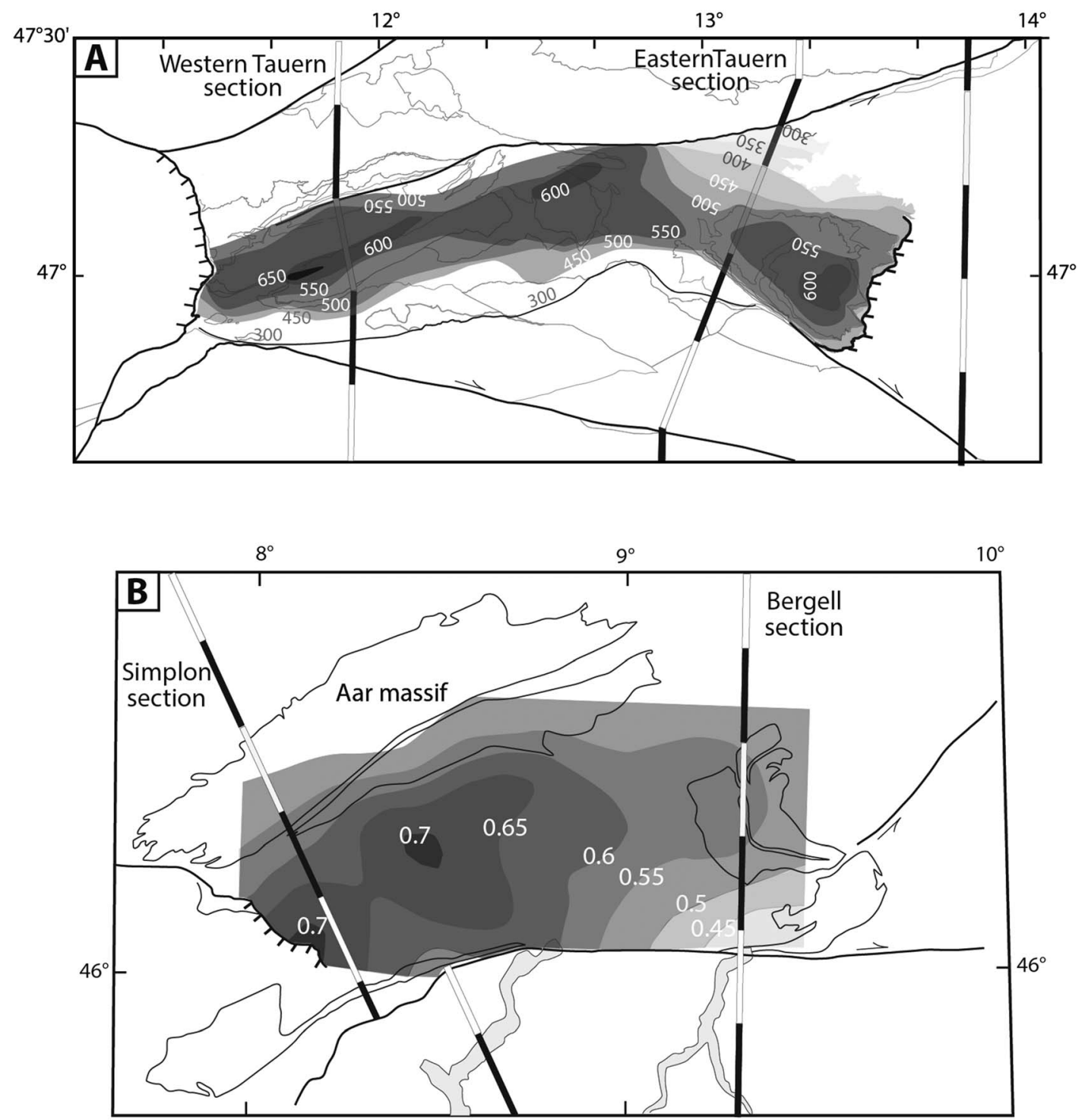

Figure 5. Spatial distribution of Alpine, HT metamorphism in the (a) Eastern Alps and of metamorphic Pressure associated to HT metamorphism in the (b) Central Alps. Temperature contours in the Eastern Alps are compiled based on Hoernes and Friedrichsen [1974], Borsi et al. [1978], and Scharf et al. [2013]. Metamorphic pressures in GPA in the Central Alps are redrawn after Engi et al. [2004].

units are nearly horizontal, suggesting negligible amounts of syncollisional shortening in the central part of the TALP. Erosion of the large-amplitude Cressim antiform results in the exposure of the deeper levels of the nappe stack, namely, the distal European nappes (Adula and Gruf complex).

The lower crust of the Adriatic plate is also interpreted to be detached from its middle and upper crusts, but the length of this lower crustal wedge (Figure 3e), i.e., displacement along the detachment, is smaller compared to the Engadine section. This displacement and the associated Miocene shortening in the Southern Alps ( 45 and $56 \mathrm{~km}$, respectively) are both smaller than in the Engadine section.

Compared to the Tauern sections, two major differences characterize the nappes geometry: the European nappes exposed in the hinge of the high-amplitude Cressim antiform are adjacent to the Periadriatic Fault, and the European basement is shortened and exhumed even north of the latter antiform, in the external part of the TALP, where it forms the external Aar Massif (Figures 1 and 3).

Shortening of the TALP in this section, excluding the amounts accommodated by transpressional deformation within the Insubric mylonitic belt, was estimated to $41 \mathrm{~km}$, equally distributed between the Aar Massif and the 
Cressim antiform [Rosenberg and Kissling, 2013]. However, recent investigations [Ortner et al., 2015] point to some $50 \mathrm{~km}$ of shortening accommodated by a series of thrusts that must have been rooted in the Aar Massif. As a consequence, bulk shortening of the TALP in this section, excluding transpressive deformation along the Insubric mylonites, is probably represented by $71 \mathrm{~km}$, resulting from $50 \mathrm{~km}$ accommodated in the external part of the chain and approximately $21 \mathrm{~km}$ [Rosenberg and Kissling, 2013] in the Cressim antiform.

\subsubsection{Simplon Section (Figure 3f)}

The TALP of this section is also shortened by two orogen-scale postnappe antiforms, but both their wavelength and their amplitude are larger compared to the Bergell section. This increase goes together with the disappearance of the long, subhorizontal, central part of the TALP, which is now reduced to a small synformal structure between the two large antiforms that overprint almost the entire TALP. The more pervasive overprinting of the TALP by orogen-scale folds, which results from larger amounts of postnappe shortening, is associated to a distributed exhumation of the deeper levels of the nappe stack. As a consequence, most of the Briançonnais and the Valais nappes are eroded, hence absent on the present-day surface of the TALP (Figure 1). A lower crustal Adriatic wedge is lacking, and the associated Miocene thrust belt affecting the Southern Alps in the other sections is strongly reduced, both in the amount of shortening $(<17 \mathrm{~km})$ and in its width (Figure 1). Note that the Monte Rosa nappe is drawn as part of the Briançonnais domain here (Figure 3f), but other interpretations suggest that it is derived from the distal European margin [Froitzheim, 2001].

Line-length balancing of the top of the Aar and Monte Rosa Massifs indicated 34 and $37 \mathrm{~km}$ of shortening, respectively [Rosenberg and Kissling, 2013]. However, the area comprised between the two massifs, where the nappes are subhorizontal, shows a severe thickening of the European basement (Figure 3f) indicating that bulk shortening of the TALP must be larger than what is accommodated by the internal and external massifs only. A crude estimation, based on area balance, hence the redistribution of the excess surface of European basement in cross section in order to restore this central area to the same thickness of the European basement below the foreland yields $\sim 24 \mathrm{~km}$ of shortening. Therefore, excluding shortening accommodated by transpressional deformation along the Insubric mylonitic belt, bulk shortening of the TALP attained $95 \mathrm{~km}$.

In summary, the three cross sections discussed above illustrate a westward increase in the amount of shortening of the TALP, which goes together with the exposure of progressively deeper structural levels (Figure 4), as described above for the Eastern Alps. The Engadine section exposes the top of the Valais nappes, but only within a tectonic window, covering a small part of the section. The overwhelming majority of the rocks exposed at the surface belong to the Austroalpine units (Figure 4), i.e., to the highest level of the Cenozoic nappe stack. Large part of the Bergell section exposes the Briançonnais and the top of the distal European basement nappes in the hinge of the Cressim antiform (Figure 3b). The Simplon section is characterized by very large exposures of European and distal European basement nappes. This trend is consistent with the spatial distribution of pressure of Barrovian metamorphism in the Central Alps [Engi et al., 2004] (Figure 5b) that shows a continuous increase from $\sim 0.45 \mathrm{GPa}$ in the Bergell area to $0.75 \mathrm{GPa}$ in the Simplon area. The lack of pressure data east of the Bergell section is due to the lack of Alpine, HT metamorphism in that area [e.g., Bousquet et al., 2012], suggesting that these units remained in the brittle field, hence at pressures most probably lower than $0.45 \mathrm{GPa}$ during Alpine subduction and collision. Therefore, the aforementioned trend of eastward decreasing pressure (Figure 5b) may well continue even east of the Bergell section. As discussed above for the Tauern Window, temperatures also show a similar trend, and increase westward, from the Bergell to the Simplon section [Engi et al., 2004].

\section{Exhumation Rates}

Assessing the age of postnappe folding based on combined geochronological [Oberli et al., 2004] and structural data [Rosenberg et al., 1995], and assessing the thickness of the crustal column that has been eroded since the beginning of postnappe folding, based on the cross sections described above allows one to infer average erosion rates since the onset of collision in different areas of the Central and Eastern Alps. We are aware that erosion rates were not constant over this range of time, but such average erosion rates are useful to detect trends and quantify long-term differences from one area (section) to the other. We plot these rates and compare them to shorter-term exhumation rates derived from thermochronological analyses in Figure 6. 
a

W
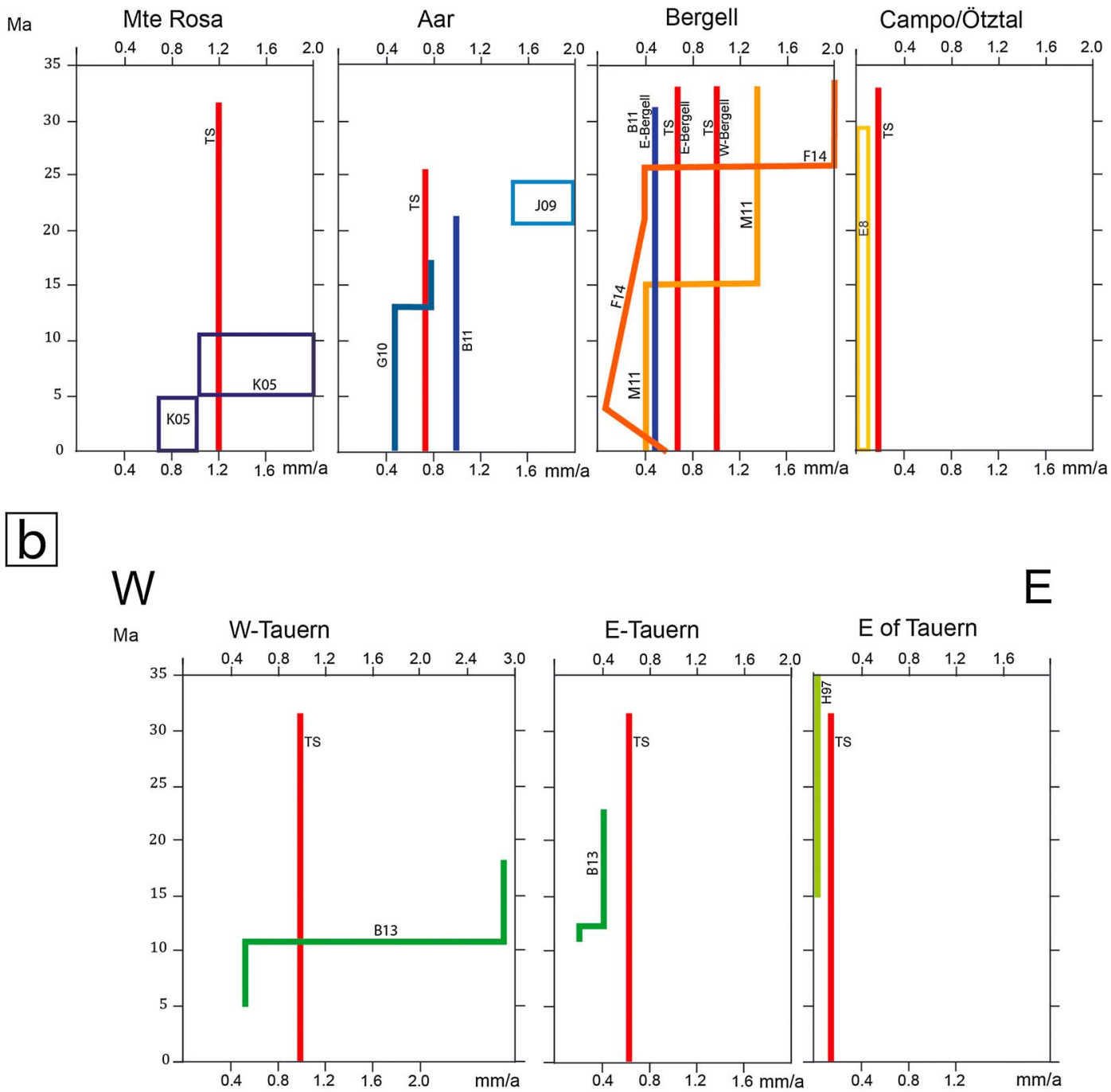

Figure 6. Compilation of exhumation rates. Where exhumation rates do not exist in the literature, they are estimated on the base of cooling ages and an assumed geothermal gradient of $25-30^{\circ} \mathrm{C}$. (a) Central Alps. (b) Eastern Alps. B11: Berger et al. [2011], B14: Bertrand [2013], F14: Fox et al. [2014], G10: Glotzbach et al. [2010], H97: Hejl [1997], J09: Janots et al. [2009], and K05: Keller et al. [2005]. TS: this study, estimated as the amount of eroded material on the base of the cross sections (Figure 3) averaged throughout collision (30 Ma).

Average erosion rates derived from our cross sections (Figure 3) would vary from point to point, being maximum in the hinges of the orogen-scale antiforms. In the plots of Figure 6, we only consider the maximum rates estimated from these hinge regions.

In the area located between the Engadine Window and the Brenner Fault (Figure 1), the thickness of the Austroalpine units at the end of the Oligocene may be reconstructed to approximately $15 \mathrm{~km}$ [Rosenberg and Garcia, 2012]. This value results from the estimated thickness of the Austroalpine nappes exposed at the surface $(\sim 10 \mathrm{~km})$ plus $4 \mathrm{~km}$ inferred on the base of thermochronological data [Fügenschuh et al., 1997] (Figure 1). Assuming that this value of $\sim 14 \mathrm{~km}$ can be applied to the rest of the Central Alps, the thickness of the crustal column eroded from the Bergell area in the past $30 \mathrm{Ma}$ is 25 to $29 \mathrm{~km}$, on top of the Aar Massif approximately $23 \mathrm{~km}$, and everywhere else in the section close to $15 \mathrm{~km}$. Therefore, the $30 \mathrm{Ma}$ long erosion of the crustal column reconstructed on top of the present-day 

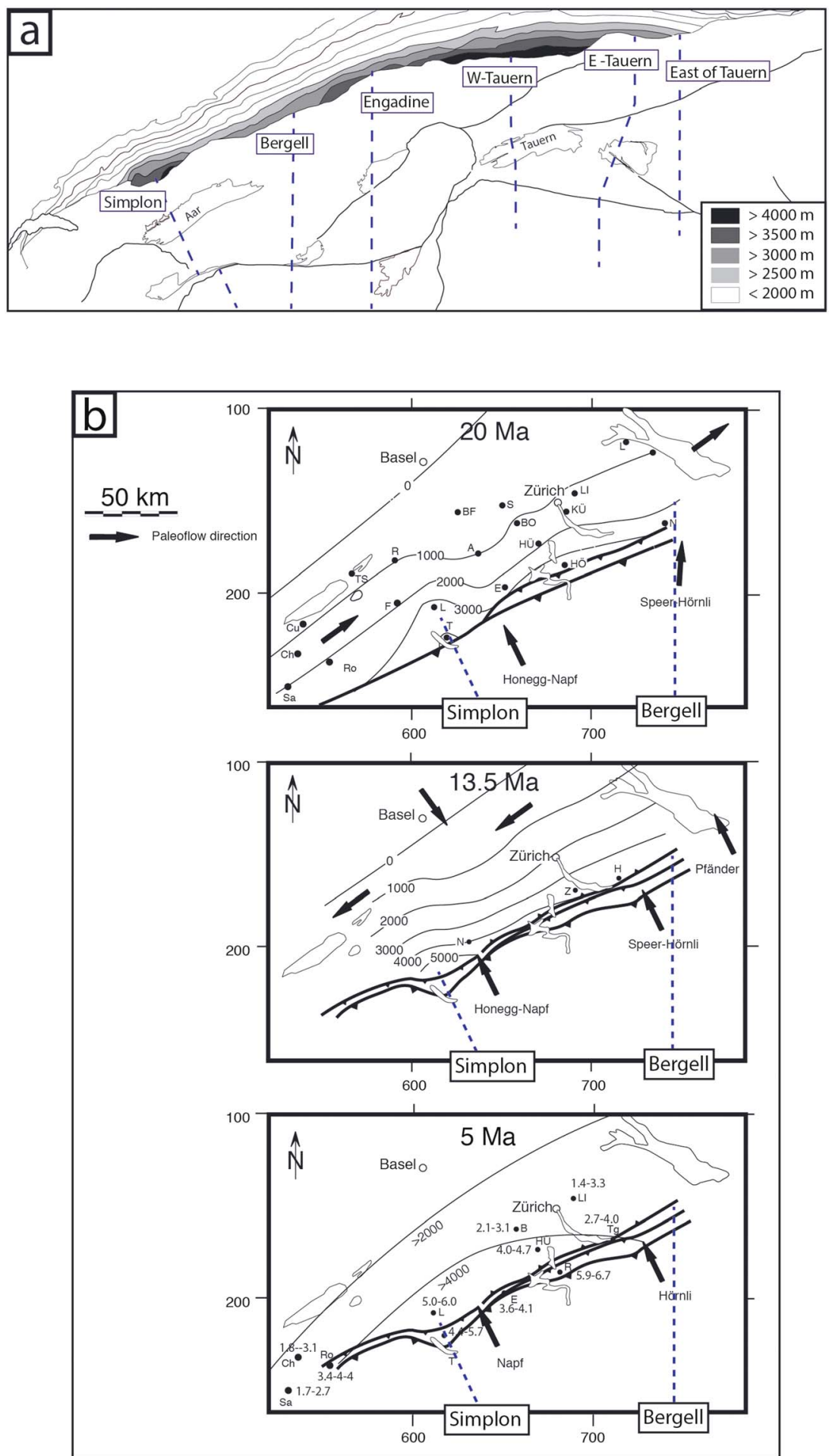

Figure 7. Thickness of sediments in the Molasse basin. (a) Contours of sediment thickness in the Molasse Basin of the Central and Eastern Alps from Bigi et al. [1990]. (b) Reconstructed contours of sediment thickness in the Molasse Basin of the Central Alps at different stages during the Tertiary. Modified from Pfiffner et al. [2002] and Schlunegger et al. [2007]. Black dots with letters indicate wells. See Pfiffner et al. [2002] for details. 


\section{A Central Alps}

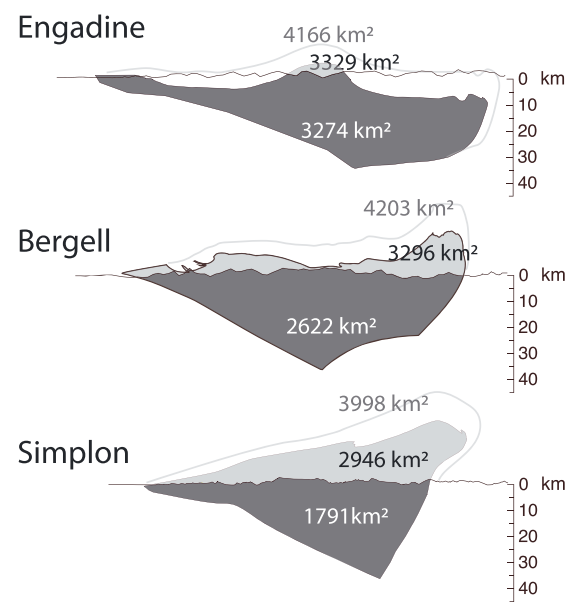

\section{B Eastern Alps}

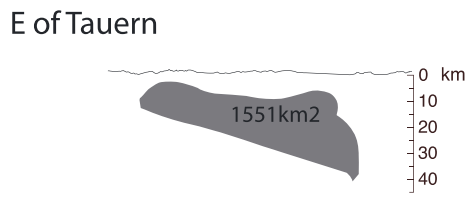

Tauern E

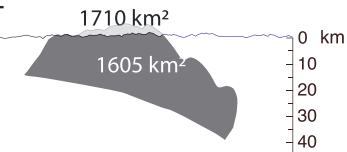

Tauern W

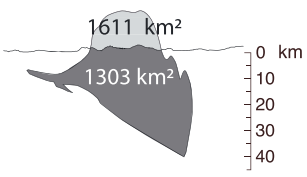

Figure 8. Cross-sectional areas of the TALP below the base of the Austroalpine nappes: (a) for the three sections of the Central Alps described in Figure 3, and (b) for the three sections of the Eastern Alps described in Figure 3. The dark gray surfaces indicate the TALP without its eroded upper part. The light gray surfaces indicate eroded portions of the TALP. The gray lines in Figure 8a indicate approximate position of the top of the Austroalpine units. The white numbers indicate cross-sectional area of TALP below present-day surface. The black numbers indicate cross-sectional area of TALP below the reconstructed base of Austroalpine. The gray numbers indicate cross-sectional area of TALP below the reconstructed top of Austroalpine.

surface of the Bergell section resulted in an average erosion rate of approximately $1.0 \mathrm{~mm} / \mathrm{a}$ in the hinge of the Cressim antiform, $0.75 \mathrm{~mm} / \mathrm{a}$ in the Aar Massif, and $0.5 \mathrm{~mm} / \mathrm{a}$ in the rest of the cross section. For the Bergell pluton, an independent estimate can be derived from the inferred depth of crystallization of the pluton at $30 \mathrm{Ma}$, as constrained from geobarometric [Davidson et al., 1996] and geochronological analyses [Oberli et al., 2004]. The inferred pressure of crystallization of $\sim 7 \mathrm{kbar}$ for the main body of the pluton [Davidson et al., 1996], corresponds to $\sim 25 \mathrm{~km}$ depth, is in good agreement with the estimated crustal column of 25-29 km eroded on top of the pluton after its emplacement.

In addition, exhumation rates can be averaged for shorter time intervals on the base of thermochronological data [e.g., Hejl, 1997; Malusà et al., 2011; Bertrand, 2013] and from P-T-t data [Berger et al., 2011; Janots et al., 2009]. Such rates are compared to the ones above in Figure 6.

\section{Along-Strike Changes of the Molasse Basin}

The present-day bulk sediment thickness in the Molasse Basin of the Central and Eastern Alps (Figure 7a) [Bigi et al., 1990] is higher in front of those parts of the orogen where lower plate shortening was larger. This is very clear in the Eastern Alps, where sediment thicknesses are $>4000 \mathrm{~m}$ in front of the western Tauern Window but decrease to $3500 \mathrm{~m}$ in front of the eastern Tauern Window (Figure 7a) and to $2000 \mathrm{~m}$ east of the Tauern Window. In the Central Alps, the highest thickness $(>4000 \mathrm{~m})$ is also found in the west, in front of the Simplon section (Figure 7a), but the eastward decrease is less obvious than in the eastern Alps (Figure 7a). Present-day variations of sediment thickness in the Molasse Basin result both from differences in the subsidence of the foreland basin and from differences in the postdepositional shortening, thickening, and erosion of the basin during its late collisional stage, which significantly affected the Molasse basin in the Central Alps [Cederboom et al., 2011]. However, even the reconstructed temporal evolution of the spatial distribution of sediment thicknesses in the foreland basin of the Central Alps (Figure 7b) [Pfiffner et al., 2002; Schlunegger et al., 2007] shows that the thickness of the Molasse sediments between $20 \mathrm{Ma}$ and the present was higher in the area of the Simplon section compared to the easternmost area, corresponding to the Engadine section. The present-day difference amount to $>500 \mathrm{~m}$ thickness (Figure 7a), whereas the reconstructed one (Figure $7 \mathrm{~b}$ ) shows lateral changes that are even more significant, attaining $>1000 \mathrm{~m}$. 
The spatial coincidence of a maximum in the Miocene thickness of Molasse sediments and in the amount of Miocene shortening of the lower plate suggests that the latter increased the load of the orogenic wedge locally enhancing subsidence of the foreland.

\section{Cross-Sectional Areas of the TALP}

In order to visualize the relationship between TALP geometry and increasing shortening in cross sections, we show and measure the reconstructed surface area of the TALP in the Central and in the Eastern Alps for each of the sections discussed above in Figure 8, choosing the base of the Austroalpine as an upper marker. This choice is arbitrary, because the latter marker does not correspond to the uppermost surface of the TALP (Figure 2), but it represents a surface whose geometry may be reconstructed in cross section.

The definition and measurement of the cross-sectional areas of the TALP are not always straight forward, especially because the geometry of the basal thrust and of the Periadriatic back thrust are not everywhere well defined at depth. For the Bergell and the Simplon sections, a direct connection along the top of the lower crust, between the lowermost thrust of the external massifs and the tip of the Adriatic lower crust (Figure 3e), was taken as the base of the TALP. The lower crust is inferred to be subducted [e.g., Schmid et al., 1996], suggesting that the base of the overlying crust is the base of the TALP. In the Engadine section, it is not easy to locate the site where thin-skinned thrusts of the Subalpine Molasse pass into the European basement; hence, it is difficult to define the base of the TALP at depth. If the transition from thinto thick-skinned tectonics is taken in a more external position, along the stippled basement thrust of Figure $3 \mathrm{~d}$, the cross-sectional area of the TALP below the Austroalpine yields $3654 \mathrm{~km}^{2}$. A more internal transition between thin- and thick-skinned deformation, along the northernmost basement thrust (not stippled in Figure 3d), yields $3329 \mathrm{~km}^{2}$ (Figure 8a).

Comparison of the three cross sections of the Central Alps indicates that higher amounts of shortening go together with thickening of the wedge, with a decrease of width, and with a steepening of its margins and internal structures (Figures 3 and 8). If the reconstructed surface area of each section is calculated, taking the base of the Austroalpine as an upper limit, we obtain 2946, 3296, and 3329 (or 3654) km², for the Simplon, the Bergell, and the Engadine wedges, respectively (Figure 8). Therefore, the area difference between them amounts to approximately $10 \%$ (20\% for the alternative interpretation of the Engadine section). Given the uncertainties of the constructions, especially in their deeper parts, the latter area differences are small, and we may consider the cross-sectional areas of the TALP to have been similar along strike.

Due to erosion, the present-day cross-sectional areas of the TALP measured below the topography are smaller compared to the reconstructed TALP cross-sectional areas. Along the Engadine section, only small amounts of the wedge have been removed by erosion $\left(55 \mathrm{~km}^{2}\right)$. In contrast, erosion reduced the surface of the wedge by 674 and by $1155 \mathrm{~km}^{2}$ in the Bergell and the Simplon sections, respectively (Figure 8 ). We emphasize that these area calculations do not include the Austroalpine units, because no appropriate markers allow us to reconstruct the top of these units. However, if their thickness is inferred to be $\leq 15 \mathrm{~km}$ in the axial part of the orogen [Rosenberg and Garcia, 2012], the top of the TALP may be sketched by the upper black line as in Figure $8 \mathrm{a}$, and in this case, the difference between the along-strike amounts of eroded cross-sectional area is much more significant, increasing from $\sim 400 \mathrm{~km}^{2}$ in the Engadine section to $\sim 2200 \mathrm{~km}^{2}$ in the Simplon section.

In the Eastern Alps, the geometries of the lower crust are less known than in the Central Alps, and external basement massifs are lacking. We therefore restrict our comparison of cross-sectional areas to the more internal part of the orogen, consisting of the stack of European basement nappes. Different interpretations of the deep structure of the western Tauern section [e.g., Schmid et al., 2004; Lammerer et al., 2011] and of the East-of-Tauern section [Schmid et al., 2004] lead to different cross-sectional areas of the TALP. Whereas our interpretation yields $1611 \mathrm{~km}^{2}$ (Figure $8 \mathrm{~b}$ ) for the western Tauern, the interpretation of Schmid et al. [2004] results in $1812 \mathrm{~km}^{2}$ (Figure 8b) and that of Lammerer et al. [2011] in $1432 \mathrm{~km}^{2}$ (Figure 8b), hence showing a variation of $\sim 15 \%$ with respect to our value. In contrast, the difference between the interpretation of Schmid et al. [2004] and our Figure 3a for the East-of-Tauern section leads to significant differences in the cross-sectional areas of the TALP, respectively, $874 \mathrm{~km}^{2}$ and $1551 \mathrm{~km}^{2}$ (Figure 8b). However if our interpretation of the deep structure of the East-of-Tauern section is taken, based on the 
line of arguments discussed in section 3.1.1, the reconstructed cross-sectional areas of the TALP in the Eastern Alps do not vary significantly $(\leq 15 \%)$ in spite of the dramatic changes of width and thickness, as already observed for the Central Alps.

The reconstructed size of the TALP in the Central Alps (Figures $3 d-3 f$ and $8 a$ ) is significantly larger than that in the Eastern Alps (Figures $3 d-3 f$ and $8 b$ ). This is mainly due to the lack of the external massifs and of the Briançonnais nappes in the Eastern Alps.

\section{Discussion}

\subsection{TALP Width Restored to Precollisional Time}

The width of the TALP along the cross sections of the Central Alps can be restored to the time preceding postnappe folding by adding the amounts of shortening defined above to its present-day width in map view. Taking $30 \mathrm{~km}, 71 \mathrm{~km}$, and $95 \mathrm{~km}$ of shortening (Figure 9) for the Engadine, Bergell, and Simplon sections (ignoring shortening accommodated along the Insubric mylonitic belt), respectively, a bulk length of 198, 206, and $191 \mathrm{~km}$ results for the Engadine, the Bergell, and the Simplon sections, respectively (Figure 1). Recalling that the amount of orogen-parallel extension in the Simplon section is probably larger, compared to the other sections [e.g., Steck, 1984; Mancktelow, 1985], the amount of $191 \mathrm{~km}$ may severely underestimate shortening. This suggests that, within an error of $\sim 10 \%$, the TALP of the Central Alps before $30 \mathrm{Ma}$ had everywhere a similar N-S extension in map view. This conclusion and comparison are based on the assumption that the northern limit of the TALP in the Simplon section is defined by the northern front of the Subalpine Molasse (Figure 1) and not by the frontal thrusts of the Jura Mountains. We use this assumption, because (1) the front of the Subalpine Molasse is represented by a continuous line all along the strike of the Central Alps, which can be compared in all three sections; (2) because the thrusts of the Jura Mountains in the continuation of the Simplon section (Figure 3f) only accommodated only few km of shortening in this lateral part of the arc and only affect the uppermost $4-5 \mathrm{~km}$ of the crust but shifted the deformation $80 \mathrm{~km}$ further north; and (3) because the shift of the orogenic front in the Jura Mountains is due to the local occurrence of unusually thick, weak salt layers [e.g., Sommaruga, 1999] that are not representative for the rest of the Alpine chain.

In the eastern Alps, a similar conclusion may be drawn. Precise shortening amounts are lacking and difficult to constrain, due to significant orogen-parallel extension, that is accommodated along large-scale strike-slip faults [Linzer et al., 2002]. A simple approach, that estimates shortening only within the antiformal stack of European basement nappes, by line-length balancing of the top of the European basement, yields shortening amounts of 27, 39, and $60 \mathrm{~km}$, from east to west, respectively (Figure 9). We emphasize that these values only consider inferred shortening in the European basement, not the absolute shortening of the cross sections. In addition, these values do not include orogen-parallel extension that was accommodated along sinistral strike-slip faults in the northern part of the TALP and dextral ones in its southern part [Linzer et al., 2002]. However, the amount of orogen-parallel displacement was inferred to be rather constant along strike [Frisch et al., 1998; Linzer et al., 2002].

If the shortening values above are used to retrodeform the width of the TALP along the three East Alpine sections (Figure 1), we obtain 170, 189, and $202 \mathrm{~km}$, for the western Tauern, eastern Tauern, and East-of-Tauern sections, respectively. As observed for the Central Alps, within an error of $\sim 15 \%$, the precollisional widths of the TALP are similar along strike. Hence, the strong gradient of shortening observed by simple line-balancing of the top of the European basement seems to explain the variation in width of the entire TALP in the Eastern Alps.

The above calculations and comparisons tacitly assume that the geometry of the European and Adriatic continental margins at the beginning of collision were straight and parallel and that collision initiated everywhere nearly at the same time. If this were not the case, shortening gradients may have resulted from large-scale geometrical irregularities of the passive margin, which would result in lateral gradients in the length of the continental (European) plate involved in the collision process. As a consequence, greater shortening could be the expression of a salient part of the continental margin before the onset of collision.

\subsection{Accommodation of Along-Strike Changes of Shortening}

The first-order structures that accommodate postnappe folding progressively change their amplitude across the strike of the Central Alps. Although we only presented six cross sections, observations of structures in 
a
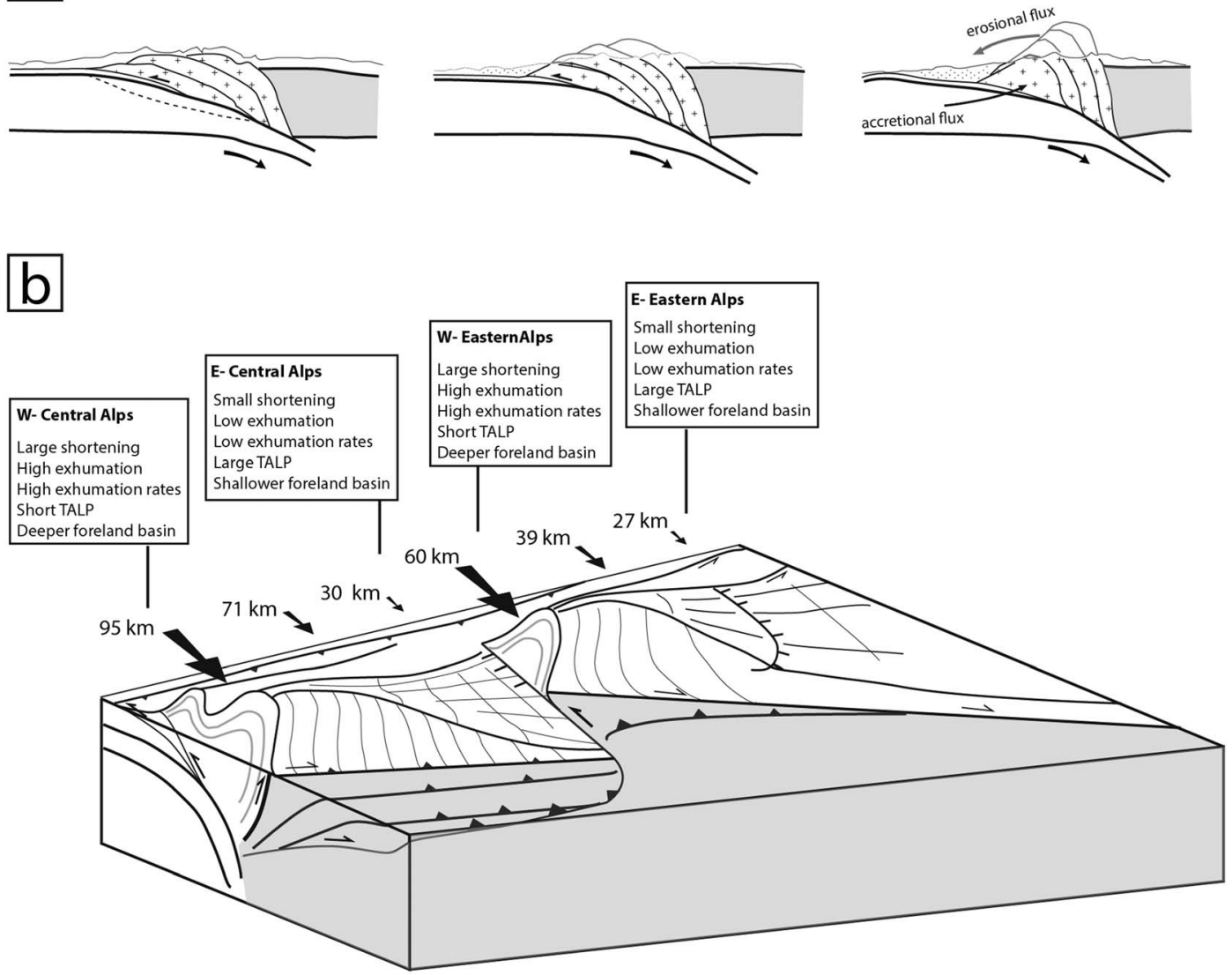

Figure 9. Schematic evolution of the TALP in (a) time and (b) space. Figure 9a shows the progressive accretion, shortening, and erosion of basement slices detached from the lower plate. Black dots: molasse basin. Stippled line: trace of future detachment. From top to bottom, the wedge margins, and the structures inside the wedge steepen, and the cross-sectional area become smaller because the erosional flux outpaces the accretional flux. Figure $9 \mathrm{~b}$ shows the 3-D block diagram illustrating along-strike geometry changes of the TALP, associated to along-strike variations of shortening. The black arrows and numbers give shortening estimates for the TALP without including shortening accommodated by strike-slip displacements.

map view, existing contour maps [Pfiffner et al., 1990; Pfiffner, 2010], and the construction of series of parallel sections [Spillmann, 1993] show that the amplification or reduction and disappearance of the large-scale folds is generally continuous and progressive along strike. For example, the Aar Massif has its culmination close to the Simplon section (Figure 1), from where it gradually decreases eastward [Pfiffner, 2010]. Although it disappears from the surface immediately west of the Bergell section, its antiformal structure continues to exist with lower amplitude even east of the Bergell section, where it forms the Prättigau half window (Figure 1) [Pfiffner, 2010]. Similarly, the Cressim antiform (Figure 1) progressively decreases its amplitude eastward, before disappearing along the Engadine section, as shown by a series of $17 \mathrm{~N}-\mathrm{S}$ striking cross sections between the Bergell and the Engadine sections [Spillmann, 1993, his Figure 4.4].

These observations are consistent with the fact that the width of the TALP does not change abruptly along first-order faults, but it continuously increases from west to east, within the Central and within the Eastern Alps. Therefore, it is the amplitude of large-scale folds in the internal part of the orogen that largely controls the width and the amount of shortening of the TALP. Only in one area this amplitude changes more abruptly, namely, across the Brenner Fault, where high-amplitude folds affect the area east of the fault and disappear to the west (Figure 1). Interestingly, this area is the only one that is affected by an orogen-scale transverse fault (Giudicarie Fault; Figure 1).

Surface areas of the TALP in cross sections (Figure 8) are relatively similar if reconstructed above the present-day surface topography but significantly different if measured below the surface. Assuming a 
time-for-space substitution such that the surface and geometry of the TALP in the less shortened sections (Engadine and East-of-Tauern) are taken to represent an initial stage of collision and the more shortened sections (Simplon and western Tauern) are taken to represent final stages of collision, the geometrical evolution of the TALP can be reconstructed through time on the base of the cross sections. Shortening accommodated by folding in the TALP leads to thickening in the nappe pile (Figure 9a). Progressive erosion of the upper part of the nappe stack counterbalances part of the thickening (Figure 9a). Because deformation does not migrate further in the external part of the basement, the cross-sectional area of the TALP decreases significantly during shortening (Figure 9a). As a consequence, the erosional flux outpaced the accretionary flux, and no "flux steady state" [Willett and Brandon, 2002] existed during collision. This observation is based on the geometry of the TALP. However, if the upper plate wedge is also considered, the conclusion above remains valid, because the size reduction of the TALP in the Simplon section is not counterbalanced by an upper plate wedge with cross-sectional area larger than those further east (Figures $3 d-3 f$ ).

Structures inherited from the pre-Alpine, Mesozoic extensional setting, may have a strong control on the localization of shortening during collision. Such structures are expected to have affected the distal margin of the European basement more than its internal part, possibly inhibiting the foreland-directed shift of the deformation front to areas that were more distant from the passive margin.

\subsection{Width of the TALP Versus Width of the Upper Plate Wedge}

Collisional shortening in the upper plate forms the Southern-Alpine thrust and fold belt south of the TALP (Figure 1). This wedge is delimited by the Periadriatic Fault in the north and by the southernmost Alpine thrust in the south, in the Po Plain (Figure 1). No systematic relationship between width of the upper plate wedge and shortening is observed. In contrast to the TALP, in the western Southern Alps, shortening increases dramatically from west to east [Schönborn, 1992], whereas the width of the upper plate wedge remains rather constant (Figure 1). In the eastern Southern Alps, no significant along-strike gradients of shortening exist [Nussbaum, 2000], but the width of the upper plate wedge decreases eastward.

The style of deformation of the upper plate wedge and the lower accreted plate show a major difference: dominant ductile folding in the lower plate and thrusting in the upper plate. As discussed above, the progressive reduction of width in the TALP is controlled by the progressive change of amplitude of orogen-scale antiforms. Such folds did not develop in the thick-skinned thrust belts of the Southern Alps (Figure 3). The different precollisional thermal history of the lower and upper plates may be the cause of these different tectonic styles. The lower plate nappes were stacked after a phase of subduction and heating in contrast to the upper plate nappes.

\subsection{Age and Duration of Differential Shortening in the Central Alpine TALP}

The northernmost continuation of the Simplon section strikes along the eastern end of the Jura Mountains (Figure 1). Miocene shortening in the Jura Mountains consisted of a thin-skinned type of deformation that only affected the uppermost $4-5 \mathrm{~km}$ of the crust, far away from the rest of the Alpine front. It was only in the Pleistocene that this deformation started to migrate into the basement of the Jura belt [Madritsch et al., 2008]. Therefore, a foreland-directed shift of the deformation front of the entire Central Alpine TALP, from the southern margin of the Molasse Basin (Figure 1) to the deformation front of the Jura Mountains, did not take place before the Pleistocene. These observations indicate that the Central Alpine TALP was able to accommodate a differential shortening of more than $70 \mathrm{~km}$ between its eastern and western ends, progressively reducing the width of its western margin during $\sim 30 \mathrm{Ma}$. It was only in the Pleistocene that the width of the Central Alpine TALP was readjusted by shifting its western thick-skinned deformation front further into the foreland, in the basement of the Jura Mountains.

\subsection{Causes of Differential Shortening in the TALP of the Central and of the Eastern Alps}

Increasing westward shortening in the TALP of the Central Alps is compensated by increasing eastward shortening in the Southern Alps [Rosenberg and Kissling, 2013]. This partitioning between the two plates during collision of the Central Alps may result from localization of shortening within the Lepontine area, during Barrovian metamorphism [Rosenberg and Kissling, 2013]. Indeed, this metamorphic event, which overprinted an earlier subduction-related event, had its peak around $30 \mathrm{Ma}$ [Rosenberg and Berger, 2009] and only affected the western part of the Central Alps, i.e., the Bergell and the Simplon sections, where the 
nappes are intensely folded (Figure 3). In the Engadine section, such a Barrovian overprint is missing, and the metamorphic record is limited to blueschist-facies conditions [Bousquet et al., 2002]. We emphasize that the lack of Barrovian metamorphism in the eastern Central Alps is not due to a lack of deeper exposure of the nappe pile [e.g., Bousquet et al., 2008]. The same tectonic units (e.g., the Valais-derived nappes; Figure 1), having the same structural level within the orogenic nappe stack, are overprinted by amphibolite-facies metamorphism in the western Central Alps and by blueschist-facies metamorphism in the Engadine area. In other words, the middle crust was affected by a significant, lateral temperature gradient. These temperature differences were inferred to explain the westward increase of localization of shortening in the TALP [Rosenberg and Kissling, 2013].

Along-strike differences of collisional shortening may also result from rheological changes within the Southern Alps. The presence of the Ivrea body in the west, building a strong, peridotitic wall from the surface down to the Moho at the front of the Southern Alps, increases the strength and reduces the ability of nucleating a decoupling horizon in the crust. The disappearance of the Ivrea body eastward may therefore allow for the internal deformation of the Southern Alps [Rosenberg and Kissling, 2013].

In summary, both within the Central Alpine TALP and within the upper plate (Southern Alps), there is good evidence for along-strike changes of crustal rheology that would explain the trends described above. Therefore, one, or both of these factors, may have acted in the Miocene to lead to the present-day partitioning of collisional shortening between the two plates.

In the eastern Alps, differential shortening of the TALP does not seem to be compensated in the Southern Alps (Dolomites), where Cenozoic shortening is rather constant along strike, at least on the scale of $60 \mathrm{~km}$ length [Nussbaum, 2000]. Hence, a clockwise rotation of the Dolomites indenter [Bertrand et al., 2015] probably occurred in order to explain the deformation gradient of the TALP. Such a rotation also explains the oblique orientation of the Pustertal and Gailtal Faults compared to the remaining parts of the Periadriatic Fault further west (Figure 1).

\subsection{Maximum Shortening and Orogen-Parallel Extension in the TALP}

Both areas corresponding to a minimum in the width of the TALP and to a maximum of collisional shortening are affected by the largest syncollisional normal faults that accommodated orogen-parallel extension: the Simplon Fault in the Central Alps and the Brenner Fault in the Eastern Alps (Figure 1). Although the amount of extension accommodated by these faults is still a matter of debate [Fügenschuh et al., 2012; Rosenberg and Garcia, 2012], it is suggested that previously calculated extensional displacements along these faults were overestimated because the contribution of folding and erosion to the exhumation of the footwalls was not taken into account (see Rosenberg and Garcia [2012] for discussion).

The spatial coincidence between extensional faults and the narrowest sections of the TALP may suggest that orogen-parallel extension controlled the reduction of width of the TALP. However, we note that the Simplon Fault is a discrete structure. Even its ductile precursor [Steck, 1984] is confined to a small area compared to the width of the Central Alps. The along-strike reduction of width and increase of shortening of the TALP is progressive over a length of $\sim 200 \mathrm{~km}$, starting from the Engadine section and continuing until the Simplon section (Figure 3). Therefore, shortening of the TALP in map view is rather controlled by folding, which does reduce its amplitude progressively from west to east, in front of each South Alpine indenter (Figure 3). This is well documented both for the Aar antiformal structure, which continuously reduces its amplitude eastward and eventually dies out west of the Engadine Window [Pfiffner et al., 1990; Pfiffner, 2010] and for the Cressim backfold (Figure 1) which also progressively reduces its amplitude eastward, completely disappearing in the Austroalpine units east of the Bergell pluton [Spillmann, 1993]. In the Eastern Alps, a similar relationship between the width of the TALP, the amplitude of upright folds, and the position of extensional faults exists. The Brenner normal fault (Figure 1) coincides with the shortest extension in map view of the TALP. However, this fault forms a localized area of extension that cannot explain a progressive widening of the TALP for over $300 \mathrm{~km}$ eastward. The Katschberg normal fault (Figure 1) located further east does not appear to affect the width of the TALP either.

E-W extension reduces the thickness of the nappe pile but not the width of the orogen in a north-south direction. However, the reduction of crustal thickness may facilitate, or at least allow for the continuation of the folding process, in areas that are already significantly thickened. 


\subsection{Correlation Between Along-Axis Variation of Exhumation Rates and Shortening}

Figure 6 shows that exhumation rates averaged over the past $30 \mathrm{Ma}$ on the base of the cross sections of Figure 3 are compatible with exhumation rates derived from thermochronometers in the same areas. In spite of significant differences between data averaged over different time intervals and on the base of different techniques, a general trend can be assessed both for the Central and for the Eastern Alps. Exhumation rates increase by $0.5-1$ order of magnitude both in the Central and in the Eastern Alps, between areas inferred to have accommodated low and high amounts of shortening, respectively, on the base of the sections discussed above. These data point to the very strong control of regional tectonics on erosion rates during collision. Inferred erosion rates averaged over a shorter time scale, namely, the last $5 \mathrm{Ma}$ [Baran et al., 2014] show the same trends described above, with an increase of 1 order of magnitude between areas located along the Engadine section and along the Simplon section. An increase of 0.5 order of magnitude in the erosion rates of the past $5 \mathrm{Ma}$ is described between the areas located east of the Tauern Window and within the Tauern Window [Baran et al., 2014].

\subsection{Can the Width/Exhumation/Shortening Correlation be Extrapolated to the Western Alps?}

The collisional history of the western Alps differs from that of the Central and Eastern Alps in terms of its timing and metamorphism. The internal massifs of the Western Alps are largely exhumed since the beginning of collision [e.g., Vernon et al., 2008], and they are not overprinted by a Barrovian metamorphism [Bousquet et al., 2008]. Collisional shortening, i.e., post-35-30 Ma deformation in the arc of the Western Alps, is almost entirely localized in the external part of the chain. As observed for the Central and Eastern Alps, the width of the TALP in the western Alps varies from about $180 \mathrm{~km}$ along the Oisans section (Figure 1) to approximately $140 \mathrm{~km}$ along the Mont Blanc section (Figure 1). These values are calculated excluding the Jura Mountains, as done for the sections discussed above. In the external crystalline massifs (Mont Blanc, Aiguilles Rouges, Oisans, Grandes Rousses, and Belledonne), OligoceneMiocene crustal shortening varies between $28 \mathrm{~km}$ in the Oisans section and $66 \mathrm{~km}$ in the Mont Blanc section [Burkhard and Sommaruga, 1998; Bellahsen et al., 2012, 2014]. Therefore, the trend correlation between TALP width and collisional shortening described above for the Central and Eastern Alps seems to hold even in the arc of the Western Alps.

\subsection{Tectonic Versus Climatic Controls on Erosion and Width of the Alps}

Exhumation rates averaged over the duration of collision increased by almost 1 order of magnitude from east to west, both in the Central (Figure 6a) and in the Eastern Alps (Figure 6b). The along-axis increase of exhumation rates correlates with the west directed amplification of folding and with the progressive decrease of orogen width in the Central and in the Eastern Alps. Therefore, shortening-induced uplift and erosion controlled the observed exhumation trend.

Erosion eliminated only few kilometers of crust east of the Tauern Window, where upright folding is absent, but increasingly higher amounts to the west, where upright folding dramatically increases in amplitude from the eastern to the western Tauern Window. The same trend is observed in the Central Alps, where the amount of erosion progressively increases from the mildly shortened TALP of the Engadine Window to the highly shortened TALP of the Simplon section. Erosion, hence climate, does play a fundamental role in the removal of very thick crustal portions during the collisional process. Without erosion, the long-term localization of shortening, hence thickening within orogen-scale antiforms such as the Cressim antiform (Figure 1) and the external massifs, would not be possible [e.g., Molnar and Lyon-Caen, 1988]. These gradients in the amount of shortening can affect erosion rates [e.g., Bonnet et al., 2007], by increasing the slope angles, without changes of climate.

The along-strike gradients of shortening described above for the TALP, indicating a twofold increase over the scale of less than $100 \mathrm{~km}$, are explained by corresponding gradients in rheology in the Central Alps [Rosenberg and Kissling, 2013] and by rotations around vertical axes in the Eastern Alps [Bertrand et al., 2015]. Paleo-climate gradients cannot explain these along-strike changes. Climate and paleo-climate barriers oriented perpendicular to the strike of orogen in these two areas are not known, and long-term differences of climate explaining along-axis alternations of high and low erosion rates on the scale of $100 \mathrm{~km}$ on a straight segment of the chain are improbable. Climate-induced changes on the rates of erosion, hence of exhumation, may have affected the Alps during collision. However, the first-order, along- 
strike changes of width, exhumation, and long-term exhumation rates appear to result from deep-seated shortening gradients which affected the Central and Eastern Alps during collision.

\section{Conclusions}

The progressive, eastward increase of width of the TALP, in front of each South Alpine indenter, correlates with a progressive decrease in the amount of collisional exhumation, with a progressive decrease of collisional shortening and with a decrease in sedimentation rates within the Molasse Basin. In spite of large uncertainties on the quantification of shortening, retrodeformation of the TALP to its precollisional state appears to eliminate most of the present-day along-strike changes of width in front of each indenter.

Erosion rates averaged over the past $30 \mathrm{Ma}$ increase by $0.5-1$ order of magnitude from east to west, in front of each South Alpine indenter. The spatial vicinity $(\sim 100 \mathrm{~km})$ of areas affected by such different erosion rates, and the absence of any evidence pointing to different paleoclimates in these areas, allows us to preclude climatic changes as primary causes for the inferred differences of erosion rates.

A systematic relationship between width and shortening cannot be assessed for the upper plate, in which shortening is accommodated by a thick- and thin-skinned thrust belt. The progressive along-strike change of width and shortening in the TALP was mainly accommodated within high-amplitude, orogen-scale folds, pointing to long-term localization of shortening. These structures did not form in the upper plate, possibly because of its different thermal history.

If the westward increase of shortening of the TALP in front of each indenter can be taken to represent the temporal evolution of the TALP through time during collision, the transition from the subhorizontal nappes in the east to tightly folded and steepened nappes in the west is inferred to represent the transition from an incipient to a very mature state of collision. This temporal evolution indicates that the cross-sectional area of the orogen decreased during collision, indicating that erosion rates outpaced accretion rates. As a consequence, if we confine our analysis to the accreted lower plate, it can be stated that the Alps were not in a flux steady state during collision.

\section{Acknowledgments}

We acknowledge Fritz Schlunegger for the discussions and for preparing Figure 7. Jacques Malavieille and Niko Froitzheim constructively reviewed this manuscript. Ralph Schuster constructively, commented a first version of the manuscript. Alain Rabaute helped us to prepare Figure 1. DFG funding (Ro 2177/4 and Ro 2177/5) are acknowledged. The data sources used to generate the figures are all quoted in the present manuscript.

\section{References}

Argand, E. (1916), Sur l'arc des Alpes Occidentales, Eclogae Geol. Helv., 14, 145-191.

Auer, M., and G. H. Eisbacher (2003), Deep structure and kinematics of the Northern Calcareous Alps (TRANSALP profile), Int. J. Earth Sci., 92, 10-227, doi:10.1007/s00531-003-0316-0.

Baran, R., A. M. Friedrich, and F. Schlunegger (2014), The late Miocene to Holocene erosion pattern of the Alpine foreland basin reflects Eurasian slab unloading beneath the Western Alps rather than global climate change, Lithosphere, 124-131.

Beaumont, C., H. Kooi, and S. Willett (1999), Coupled tectonic-surface process models with applications to rifted margins and collisional orogens, in Geomorphology and Global Tectonics, edited by M. A. Summerfield, pp. 29-52, John Wiley, Chichester.

Behrmann, J. H., and D. C. Tanner (2006), Structural synthesis of the Northern Calcareous Alps, TRANSALP segment, Tectonophysics, 414, 225-240.

Bellahsen, N., L. Jolivet, O. Lacombe, M. Bellanger, A. Boutoux, S. Garcia, F. Mouthereau, L. Le Pourhiet, and C. Gumiaux (2012), Mechanisms of margin inversion in the external Western Alps: Implications for crustal rheology, Tectonophysics, 560-561, 62-83.

Bellahsen, N., F. Mouthereau, A. Boutoux, M. Bellanger, O. Lacombe, L. Jolivet, and Y. Rolland (2014), Collision kinematics in the Western Alps, Tectonics, 33, 1055-1088, doi:10.1002/2013TC003453.

Berger, A., and R. Bousquet (2008), Subduction-related metamorphism in the Alps: Review of isotopic ages based on petrology and their geodynamic consequences, in Tectonic Aspects of the Alpine-Dinaride-Carpathian System, vol. 298, edited by S. Siegesmund, B. Fügenschuh, and N. Froitzheim, pp. 117-144, Geol. Soc. Spec. Publ., London.

Berger, A., C. L. Rosenberg, and S. M. Schmid (1996), Ascent, emplacement and exhumation of the Bergell pluton within the Southern Steep Belt of the Central Alps, Schweiz. Mineral. Petrogrogr. Mitt., 76, 357-382.

Berger, A., S. M. Schmid, M. Engi, R. Bousquet, and M. Wiederkehr (2011), Mechanisms of mass and heat transport during Barrovian metamorphism: A discussion based on field evidence from the Central Alps (Switzerland/northern Italy), Tectonics, 30, TC1007, doi:10.1029/2009TC002622.

Bertrand, A. (2013), Exhuming the core of collisional orogens, the Tauern Window (Eastern Alps) A geochronological, modelling and structural work, PhD thesis, Freie Universität Berlin, Switzerland, $195 \mathrm{pp}$.

Bertrand, A., C. L. Rosenberg, and S. Garcia (2015), Fault slip analysis and late exhumation of the TauernWindow, Eastern Alps, Tectonophysics, $649,1-17$.

Bigi, G., A. Castellarin, M. Coli, G. V. Dal Piaz, M. Sartori, P. Scandone, and G. B. Vai (1990), Structural Model of Italy, SELCA, Florence, Italy.

Bleibinhaus, F., and R. Groshup (2008), Structure of the Periadriatic Fault in the Eastern Alps from reflection seismic imaging, EOs Trans. AGU 89.53 Suppl., Poster S11C-1771.

Bonnet, C., J. Malavieille, and J. Mosar (2007), Interactions between tectonics, erosion, and sedimentation during the recent evolution of the Alpine orogen: Analogue modeling insights, Tectonics, 26, TC6016, doi:10.1029/2006TC002048.

Borsi, S., A. Del Moro, F. P. Sassi, A. Zanferrari, and G. Zirpoli (1978), New geopetrologic and radiometric data on the Alpine history of the Austridic continental margin south of the Tauern Window (Eastern Alps), Mem. Inst. Geol. Mineral. Univ. Padova, $32,17$. 
Bousquet, R., B. Goffé, O. Vidal, R. Oberhänsli, and M. Patriat (2002), The tectono-metamorphic history of the Valaisan domain from the Western to the Central Alps: New constraints for the evolution of the Alps, Bull. Geol. Soc. Am., 114, 207-225.

Bousquet, R., R. Oberhänsli, B. Goffé, M. Wiederkehr, F. Koller, S. M. Schmid, R. Schuster, M. Engi, A. Berger, and G. Martinotti (2008), Metamorphism of metasediments at the scale of an orogen: A key to the Tertiary geodynamic evolution of the Alps, in Tectonic Aspects of the Alpine-Dinaride-Carpathian System, vol. 298, edited by S. Siegesmund, B. Fügenschuh, and N. Froitzheim, pp. 393-411, Geol. Soc. Spec. Publ., London.

Bousquet, R., R. Oberhansli, S. M. Schmid, A. Berger, M. Wiederkehr, C. Robert, C. L. Rosenberg, F. Koller, G. Molli, and G. Zeilinger (2012), Metamorphic framework of the Alps CCGM/CGMW.

Brix, F., and O. Schultz (1993), Erdöl und Erdgas in Österreich Veröff. Naturhist. Mus. Wien, 19. Horn. 668 pp.

Burkhard, M., and A. Sommaruga (1998), Evolution of the western Swiss Molasse Basin: Structural relations with the Alps and the Jura belt, in Cenozoic Foreland Basins of Western Europe, vol. 34, edited by A. Mascle et al., pp. 279-298, Geol. Soc. Spec. Publ., London.

Castellarin, A., and L. Cantelli (2000), Neo-Alpine evolution of the southern Eastern Alps, J. Geodyn., 30, 251-274.

Cederboom, C. E., P. van der Beek, F. Schlunegger, H. D. Sinclair, and O. Oncken (2011), Rapid extensive erosion of the North Alpine foreland basin at 5-4 Ma, Basin Res., 23(5), 528-550, doi:10.1111/j.1365-2117.2011.00501.x.

Dahlen, F. A. (1990), Critical taper model of fold-and-thrust belts and accretionary wedges, Annu. Rev. Earth Planet. Sci., 18, 55-99.

Davidson, C., C. L. Rosenberg, and S. M. Schmid (1996), Synmagmatic folding of the base of the Bergell pluton: Evidence from the western contact, Tectonophysics, 265, 213-238.

Elter, G. (1971), Schistes lustrés et ophiolites de la zone piémontaise, entre Orco et Doire Baltée (Alpes Graies). Hypothèses sur l'origine des ophiolites, Géol. Alp., 47, 147-169.

Engi, M., R. Bousquet, and A. Berger (2004), Explanatory notes to the map: Metamorphic structure of the Alps, Central Alps, Mitt. Österr. Mineral. Ges., 149, 157-173.

Evans, S. L. (2011), Timing of exhumation of the eastern Central Alps from zircon and apatite (U-Th)/He thermochronology (Graubünden, Switzerland) Master of Science, Univ. of Kansas, Lawrence.

Exner, C. (1964), Erläuterungen zur Geologischen Karte der Sonnblickgruppe, 130 pp., Geologische Bundesanstalt, Wien.

Fox, M., R. Reverman, F. Herman, M. Fellin, P. Sternai, and S. D. Willett (2014), Rock uplift and erosion rate history of the Bergell intrusion from the inversion of low temperature thermochronometric data, Geochem., Geophys., Geosyst., 15, 1235-1257, doi:10.1002/ 2013 GC005224.

Frisch, W., A. Kuhlemann, I. Dunkl, and A. Brügel (1998), Palinspastic reconstruction and topographic evolution of the Eastern Alps during late Tertiary tectonic extrusion, Tectonophysics, 297, 1-15.

Froitzheim, N. (2001), Origin of the Monte Rosa nappe in the Pennine Alps-A new working hypothesis, Geol. Soc. Am. Bull., 113, 604-614.

Froitzheim, N., S. M. Schmid, and M. Frey (1996), Mesozoic paleogeography and the timing of eclogite facies metamorphism in the Alps: A working hypothesis, Eclogae Geol. Helv., 89, 81-110.

Fügenschuh, B., D. Seward, and N. S. Mantckelow (1997), Exhumation in a convergent orogen: The western Tauern Window, Terra Nova, 9 , 213-217.

Fügenschuh, B., N. S. Mantckelow, and S. M. Schmid (2012), Comment on "Estimating displacement along the Brenner Fault and orogenparallel extension in the Eastern Alps" by Rosenberg and Garcia, Int. J. Earth Sci. (Geol. Rundsch.), 100, 1129-1145.

Glotzbach, C., J. Reinecker, M. Danišík, M. Rahn, W. Frisch, and C. Spiegel (2010), Thermal history of the central Gotthard and Aar Massifs, European Alps: Evidence for steady state, long-term exhumation, J. Geophys. Res., 115, F03017, doi:10.1029/2009JF001304.

Handy, M. R., and R. Oberhänsli (2004), Age of the metamorphic structure of the Alps-Tectonic interpretation and outstanding problems, in Explanatory Notes to the Map: Metamorphic Structure of the Alps, Mitt. Öesterr. Mineral. Ges., vol. 149, edited by R. Oberhänsli, pp. 97-121, Österr. Mineral. Ges., Wien, Austria.

Hejl, E. (1997), Cold spots' during the Cenozoic evolution of the Eastem Alps: Thermochronological interpretation of apatite fission-track data, Tectonophysics, 272, 159-173.

Hitz, L. (1995), The 3D crustal structure of the Alps of eastern Switzerland and western Austria interpreted from a network of deep-seismic profiles, Tectonophysics, 248, 71-96.

Hoernes, S., and H. Friedrichsen (1974), Oxygen isotope studies on metamorphic rocks of the western Hohe Tauern area (Austria), Schweiz. Mineral. Petrogr. Mitt., 54, 769-788.

Hoth, S., J. Adam, N. Kukowski, and O. Oncken (2006), Influence of erosion on the kinematics of bivergent orogens: Results from scaled sandbox simulations, in Tectonics, Climate, and Landscape Evolution, vol. 398, pp. 201-225, Spec. Pap. Geol. Soc. Am., Boulder, Colo.

Janots, E., M. Engi, D. Rubatto, A. Berger, and M. Rahn (2009), Metamorphic rates in collisional orogeny from in situ allanite and monazite dating, Geology, 37, 11-14.

Keller, L., M. Hess, B. Fügenschuh, and S. Schmid (2005), Structural and metamorphic evolution of the Camughera-Moncucco, Antrona and Monte Rosa units southwest of the Simplon line, Western Alps, Eclogae Geol. Helv., 98, 19-49, doi:10.1007/s00015-005-1149-6.

Konstantinovskaia, E., and J. Malavieille (2005), Erosion and exhumation in accretionary orogens: Experimental and geological approaches, Geochem., Geophys., Geosyst., 6, Q02006, doi:10.1029/2004GC000794.

Kuhlemann, J., W. Frisch, B. Szekely, I. Dunkl, and M. Kazmer (2002), Post-collisional sediment budget history of the Alps: Tectonic versus climatic control, Int. J. Earth Sci., 91, 818-837, doi:10.1007/s00531-002-0266-y.

Lammerer, B., and M. Weger (1998), Footwall uplift in an orogenic wedge: The Tauern Window in the Eastern Alps of Europe, Tectonophysics, 285, 213-230.

Lammerer, B., H. Gebrande, E. Lüschen, and P. Vesela (2008), A crustal-scale cross-section through the Tauern Window (Eastern Alps) from geophysical and geological data, in Tectonic Aspects of the Alpsine-Carpathian-Dinaride System, vol. 298, edited by S. Siegesmund, B. Fügenschuh, and N. Froitzheim, pp. 219-229, Geol. Soc. Spec. Publ., London.

Lammerer, B., J. Selverstone, and G. Franz (2011), Field trip to the Tauern Window region along the TRANSALP seismic profile, Eastern Alps, Austria, in Geological Field Trips in Central Western Europe: Fragile Earth International Conference, Field Guide, vol. 22, edited by S. Carena, A. M. Friedrich, and B. Lammerer, pp. 20, Geol. Soc. Am. Munich.

Laubscher, H. P. (1983), Detachment, shear and compression in the Central Alps, Geol. Soc. Am. Mem., 158, $191-211$.

Laubscher, H.-P. (1988), Material balance in Alpine orogeny, Geol. Soc. Am. Bull., 100, 1313-1328.

Laubscher, H.-P. (1990), The problem of the deep structure of the Southern Alps: 3-D material balance considerations and regional consequences, Tectonophysics, 176, 103-121.

Linzer, H.-G., K. Decker, H. Peresson, R. Dell'Mour, and W. Frisch (2002), Balancing orogenic float of the Eastern Alps, Tectonophysics, 354, 211-237. 
Luth, S. W., and E. Willingshofer (2008), Mapping of the post-collisional cooling history of the Eastern Alps Swiss, J. Geosci., 101, 207-223, doi:10.1007/s00015-008-1294-9.

Madritsch, H., S. M. Schmid, and O. Fabbri (2008), Interactions between thin- and thick-skinned tectonics at the northwestern front of the Jura fold-and-thrust belt (eastern France), Tectonics, 27, TC5005, doi:10.1029/2008TC002282.

Malusà, M. G., I. G. Villa, G. Vezzoli, and E. Garzanti (2011), Detrital geochronology of unroofing magmatic complexes and the slow erosion of Oligocene volcanoes in the Alps, Earth Planet. Sci. Lett., 301, 324-336.

Mancktelow, N. S. (1985), The Simplon Line: A major displacement zone in the western Lepontine Alps, Eclogae Geol. Helv., $78,73-96$.

Milnes, A. G. (1974), Post-nappe folding the the western Lepontine Alps, Eclogae Geol. Helv., 67, 333-348.

Molnar, P., and H. Lyon-Caen (1988), Some simple physical aspects of the support, structure, and evolution of mountain belts, Spec. Pap. Geol. Soc. Am., 218, 179-614.

Nussbaum, C. (2000), Neogene tectonics and thermal maturity of sediments of the easternmost Southern Alps (Friuli area, Italy), PhD Thesis, Univ. of Neuchâtel, Switzerland.

Oberli, F., M. Meier, A. Berger, C. L. Rosenberg, and R. Gieré (2004), U-Th-Pb and ${ }^{230} \mathrm{Th} /{ }^{238} \mathrm{U}$ disequilibrium isotope systematics: Precise accessory mineral chronology and melt evolution tracing in the Alpine Bergell intrusion, Geochim. Cosmochim. Acta, 68, 2543-2560.

Ortner, H., F. Reiter, and F. Brandner (2006), Kinematics of the Inntal shear zone-sub-Tauern ramp fault system and the interpretation of the TRANSALP seismic section, Eastern Alps, Austria, Tectonophysics, 414, 241-258.

Ortner, H., S. Aichholzer, M. Zerlauth, R. Pilser, and B. Fügenschuh (2015), Geometry, amount, and sequence of thrusting in the Subalpine Molasse of western Austria and southern Germany, European Alps, Tectonics, 34, 1-30, doi:10.1002/2014TC003550.

Pfiffner, A. O. (1993), Palinspastic reconstruction of the pre-Triassic basement units in the Alps: The Central Alps, in Pre-Mesozoic Geology in the Alps, edited by J. F. von Raumer and F. Neubauer, pp. 29-39, Springer, Berlin, doi:10.1007/978-3-642-84640-3_3.

Pfiffner, O. A. (2010), Geologie der Alpen 2. Erweiterte Auflage UTB / Haupt Verlag 359 pp.

Pfiffner, O. A., E. M. Klaper, A. M. Mayerat, and P. Heitzmann (1990), Structure of the basement-cover contact in the Swiss Alps, Mém. Soc. Géol. Fr., 156, 247-262.

Pfiffner, A. O., F. Schlunegger, and S. J. H. Buiter (2002), The Swiss Alps and their peripheral foreland basin: Stratigraphic response to deep crustal processes, Tectonics, 21(2), 1009, doi:10.1029/2000TC900039.

Pomella, H., U. Klötzli, R. Scholger, M. Stipp, and B. Fügenschuh (2011), The Northern Giudicarie and the Meran-Mauls Fault (Alps, northern Italy) in the light of new paleomagnetic and geochronological data from boudinaged Eo-/Oligocene tonalites, Int. J. Earth Sci. (Geol. Rundsch.), 100, 1827-1850, doi:10.1007/s00531-010-0612-4.

Ratschbacher, L., O. Merle, P. Davy, and P. Cobbold (1991), Lateral extrusion in the Eastern Alps, Part 1: Boundary conditions and experiments scaled for gravity, Tectonics, 10, 245-256, doi:10.1029/90TC02622.

Rosenberg, C. L., and A. Berger (2009), On the causes and modes of exhumation and lateral growth of the Alps, Tectonics, 28, TC6001, doi:10.1029/2008TC002442.

Rosenberg, C. L., and S. Garcia (2012), Reply to the comment of Fügenschuh et al. on the paper "Estimating displacement along the Brenner Fault and orogen-parallel extension in the Eastern Alps" by Rosenberg and Garcia, Int. J. Earth Sci. (Geol. Rundsch.), 100, 1129-1145, doi:10.1007/s00531-011-0726-3.

Rosenberg, C. L., and F. Heller (1997), Tilting of the Bergell pluton and central Lepontine area: Combined evidence from paleomagnetic, structural and petrological data, Eclogae Geol. Helv., 90, 345-356.

Rosenberg, C. L., and E. Kissling (2013), Three-dimensional insight into Central-Alpine collision: Lower-plate or upper-plate indentation?, Geology, 41, 1219-1222.

Rosenberg, C. L., A. Berger, and S. M. Schmid (1995), Observations from the floor of a granitoid pluton: Inferences on the driving force of final emplacement, Geology, 23, 443-446.

Scharf, A., M. R. Handy, M. A. Ziemann, and S. M. Schmid (2013), Peak-temperature patterns of polyphase metamorphism resulting from accretion, subduction and collision (eastern Tauern Window, European Alps)—A study with Raman microspectroscopy on carbonaceous material (RSCM), J. Metamorph. Geol., 31, 863-880.

Schlunegger, F. (1999), Controls of surface erosion on the evolution of the Alps: Constraints from the of the adjacent foreland basins, Int. J. Earth Sci., 88, 285-304, doi:10.1007/s005310050265.

Schlunegger, F., and G. Simpson (2002), Possible erosional control on lateral growth of the European Central Alps, Geology, 30, 907-910.

Schlunegger, F., D. Rieke-Zapp, and K. Ramseyer (2007), Possible environmental effects on the evolution of the Alps-Molasse Basin system, Swiss J. Geosci., 100, 383-405.

Schmid, S., O. A. Pfiffner, N. Froitzheim, G. Schönborn, and E. Kissling (1996), Geophysical-geological transect and tectonic evolution of the Swiss-Italian Alps, Tectonics, 15, 1036-1064, doi:10.1029/96TC00433.

Schmid, S. M., and E. Kissling (2000), The arc of the Western Alps in the light of geophysical data on deep crustal structure, Tectonics, 19, 62-85, doi:10.1029/1999TC900057.

Schmid, S. M., B. Fügenschuh, E. Kissling, and R. Schuster (2004), Tectonic map and overall architecture of the Alpine orogen, Eclogae Geol. Helv., 97, 93-117, doi:10.1007/s00015-004-1113-x.

Schmid, S. M., A. Scharf, M. R. Handy, and C. L. Rosenberg (2013), The Tauern Window (Eastern Alps, Austria): A new tectonic map, with crosssections and a tectonometamorphic synthesis, Swiss J. Geosci., 106, 1-32.

Schönborn, G. (1992), Alpine tectonics and kinematic models of the central Southern Alps, Mem. Sci. Geol. Padova, 44, 229-293.

Sommaruga, A. (1999), Décollement tectonics in the Jura foreland fold-and-thrust belt, Mar. Pet. Geol., 16, 111-134.

Spada, M., I. Bianchi, E. Kissling, N. Piana Agostinetti, and S. Wiemer (2013), Combining controlled-source seismology and receiver function information to derive 3-D Moho topography for Italy, Geophys. J. Int., 194(2), 1050-1068, doi:10.1093/gji/ggt148.

Spillmann, P. (1993), Die Geologie des penninisch-ostalpinen Grenzbereichs im südlichen Berninagebirge, PhD, ETH Zuerich, Nr. 10175.

Stampfli, G. (1993), Le Briançonnais: Terrain exotique dans les Alpes?, Eclogae Geol. Helv., 86, 1-45.

Steck, A. (1984), Structures de déformations tertiaires dans les Alpes centrales (transversale Aar-Simplon-Ossola), Eclogae Geol. Helv., 77, 55-100.

Steinmann, M., and P. Stille (1999), Geochemical evidence for the nature of the crust beneath the eastern North Penninic basin of the Mesozoic Tethys ocean, Geol. Rundsch., 87, 633-643.

Tomkin, J. H., and G. H. Roe (2007), Climate and tectonic controls on critical taper orogens, Earth Planet. Sci. Lett., 262, $385-397$.

TRANSALP Working Group (2002), First deep seismic reflection images of the Eastern Alps reveal giant crustal wedges and transcrustal ramps, Geophys. Res. Lett., 29(10), 1452, doi:10.1029/2002GL014911.

Trümpy, R. (1980), Geology of Switzerland, 104, pp., Wepf, Basel.

Trümpy, R. (2002), Trying to understand Alpine sediments-Before 1950, Earth Sci. Rev., 61, 19-42. 
Vernon, A. J., P. A. van der Beek, H. D. Sinclair, and M. K. Rahn (2008), Increase in late Neogene denudation of the European Alps confirmed by analysis of a fission-track thermochronology database, Earth Planet. Sci. Lett., 270, 316-329, doi:10.1016/j.epsl.2008.03.053.

Whipple, K. (2009), The influence of climate on the tectonic evolution of mountain belts, Nat. Geosci., 2, 97-104, doi:10.1038/ngeo413.

Willenbring, J. K., and F. von Blanckenburg (2010), Long-term stability of global erosion rates and weathering during late-Cenozoic cooling, Nature, 465, 211-214, doi:10.1038/nature09044.

Willett, S., C. Beaumont, and P. Fullsack (1993), Mechanical model for the tectonics of doubly vergent compressional orogens, Geology, 21, 371-374.

Willett, S. D. (1999), Orogeny and orography: The effects of erosion on the structure of mountain belts, J. Geophys. Res., 104, 28,957-28,981, doi:10.1029/1999JB900248.

Willett, S. D. (2010), Late Neogene erosion of the Alps: A climate driver?, Annu. Rev. Earth Planet. Sci., 38, 411-437, doi:10.1146/annurev-earth040809-152543

Willett, S. D., and M. Brandon (2002), On steady states in mountain belts, Geology, 2002(30), 175-178.

Willett, S. D., F. Schlunegger, and V. Picotti (2006), Messinian climate change and erosional destruction of the central European Alps, Geology, 34, 613-616.

Wölfler, A., W. Kurz, H. Fritz, and K. Stüwe (2011), Lateral extrusion in the Eastern Alps revisited: Refining the model by thermochronological, sedimentary, and seismic data, Tectonics, 30, TC4006, doi:10.1029/2010TC002782. 